$$
\begin{aligned}
& \text { ORNL-3376 } \\
& \text { C-44b - Nuclear Technology-Chemistry } \\
& \text { and Chemical Engineering }
\end{aligned}
$$

\title{
LABORATORY DEVELOPMENT OF CHLORIDE
}

VOLATILITY PROCESSES FOR THE RECOVERY

OF URANIUM DIRECTLY FROM SPENT ROVER

FUEL OR FROM ITS COMBUSTION ASH

T. A. Gens

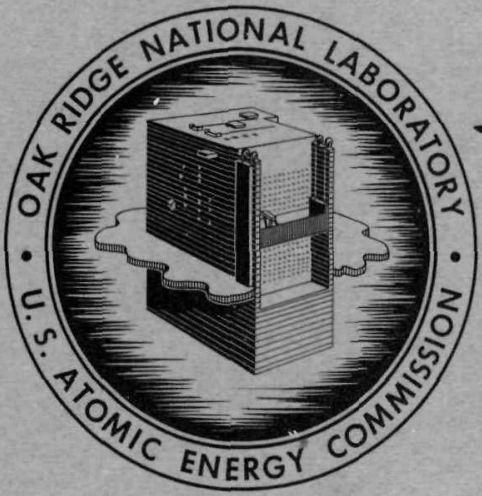

OAK RIDGE NATIONAL LABORATORY

$$
\text { operated by }
$$

UNION CARBIDE CORPORATION

for the

U.S. ATOMIC ENERGY COMMISSION

UNCLASSIFIED

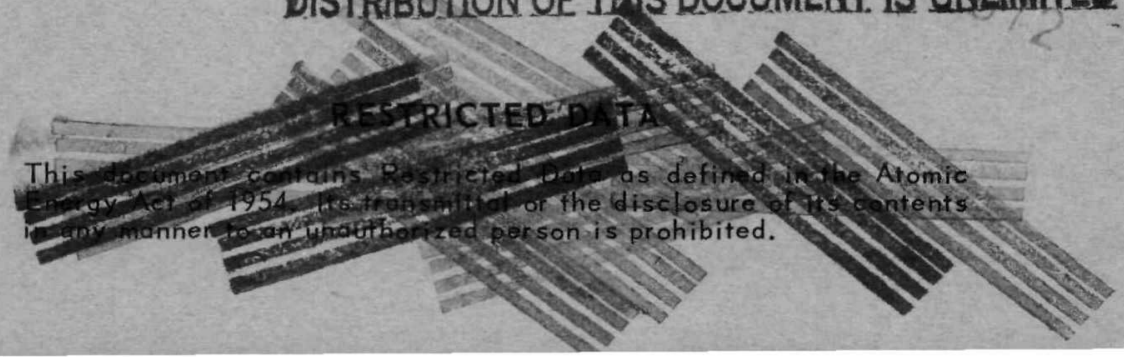




\section{DISCLAIMER}

This report was prepared as an account of work sponsored by an agency of the United States Government. Neither the United States Government nor any agency Thereof, nor any of their employees, makes any warranty, express or implied, or assumes any legal liability or responsibility for the accuracy, completeness, or usefulness of any information, apparatus, product, or process disclosed, or represents that its use would not infringe privately owned rights. Reference herein to any specific commercial product, process, or service by trade name, trademark, manufacturer, or otherwise does not necessarily constitute or imply its endorsement, recommendation, or favoring by the United States Government or any agency thereof. The views and opinions of authors expressed herein do not necessarily state or reflect those of the United States Government or any agency thereof. 


\section{DISCLAIMER}

Portions of this document may be illegible in electronic image products. Images are produced from the best available original document. 
This report was prepared as an account of Government sponsored work. Neither the United States, nor the Commission, nor any person acting on behalf of the Commission:

A. Makes any warranty or representation, expressed or implied, with respect to the accuracy, completeness, or usefulness of the information contained in this report, or that the use of any information, apparatus, method, or process disclosed in this report may not infringe privarely owned rights; or

B. Assumes any liabilities with respect to the use of, or for damages resulting from the use of any information, apparatus, method, or process disclosed in this report.

As used in the above, "person acting on behalf of the Commission" includes any employee or contractor of the Commission, or employee of such contractor, to the extent that such employee or contractor of the Commission, or employee of such contractor prepares, disseminates, or provides access to, any information pursuant to his employment or contract with the Commission, or his employment with such contractor. 
NOTICE

This report was prepared as an account of work sponsored by the United States Government. Neither the United States nor the United States Atomic Energy Commission, nor any of their employees, nor any of their contractors, subcontractors, or their employees, ma makes any warranty, expibility for the accuracy, comlegal liability or respon ibility forf the pleteness or usefulness of any represents that its use product or process disclosed, or represents
would not infringe privately owned rights.

\section{UNCLASSIFIED}

ORNL-3376

Contract No. W-7405-eng-26

CHEMICAL TECHNOLOGY DIVISION

Chemical Development section B

LABORATORY DEVELOPMENT OF CHIORIDE VOLATILITY PROCESSES FOR THE RECOVERY OF URANIUM DIRECTLY FROM SPENT ROVER FUEL OR FROM ITS COMBUSTION ASH

T. A. Gens

Technician: E. R. Johns

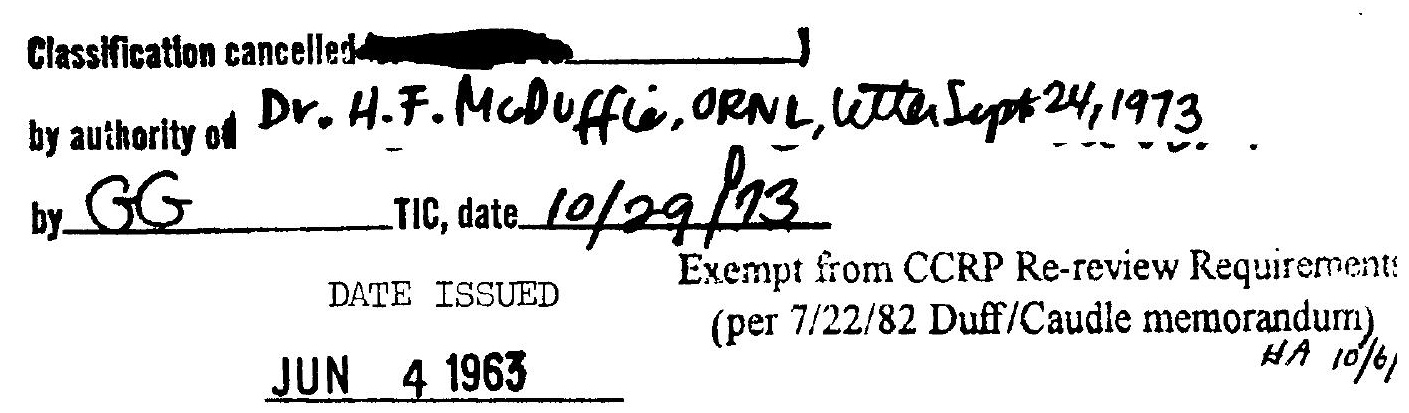

OAK RIDGE NATIONAL IABORATORY

Oak Ridge, Tennessee

operated by

UNION CARBIDE CORPORATION

for the

U.S. ATOMIC ENERGY COMMISSION

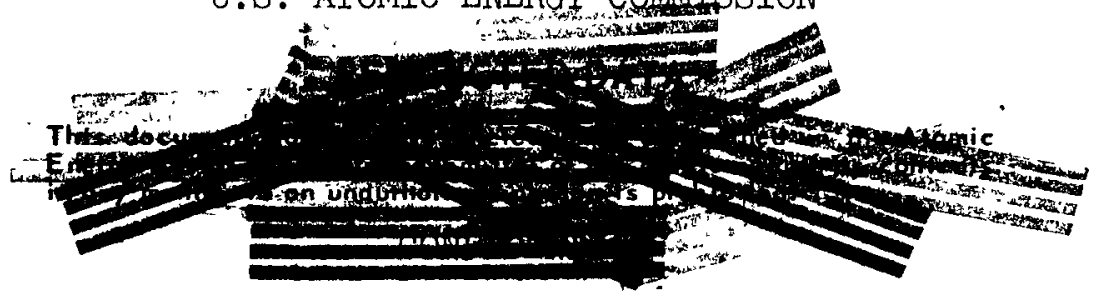


Blank Page 


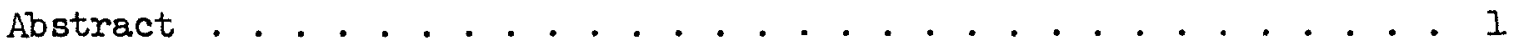

1. Introduction ................. 2

2. Flowsheets ................... 3

2.I Discussion of the Combustion-Chlorination-Selective Volatilization Procedure ............ 3

2.1.1 Basic Steps .................. 3

2.1.2 Routes that may be taken after the Chlorination step. 7

2.1.3 Possibilities for Decontaminating the Uranium . . . 8

2.2 Discussion of the Direct ChIorination Process (not

Preceded by Burning in Oxygen) .......... 8

3. Chemistry of the Chlorination Processes . . . . . . . . . . . . . II

4. Chlorination Experiments and Results. . . . . . . . . . . 15

4.1 Chlorination of Combustion Ash . . . . . . . . . . . . 15

4.2 Direct Chlorination of Graphite Fuels . . . . . . . . . . . 19

4.2.1 Uncoated Fuels . . . . . . . . . . . . . . . 19

4.2.2 Problems Presented by Fuels Coated with Niobium

Carbide . . . . . . . . . . . . . 19

5. Discussion of Corrosion Rates and Suitable Materials of

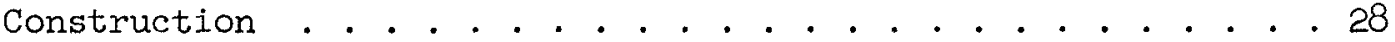

6. Conclusions and Recommendations............... . . 31

7. References .................. 32 
LABORATORY DEVELOPMENT OF CHLORIDE VOLATILITY PROCESSES FOR THE RECOVERY OF URANIUM DIRECTLY FROM SPENT ROVER FUEL OR FRON ITS COMBUSTION ASH

T. A. Gens

\section{ABSTRACT}

Two chloride volatility processes for the recovery of uranium from the combustion ash from spent Rover fuel were studied in the laboratory. The fuel consists of graphite impregnated with uranium carbide. The cooling channels are of niobium carbide. In each method, the uranium is isolated as $\mathrm{UCl}_{4}$ and it may be further processed by aqueous solvent extraction (Darex) or fluoride volatility methods. The combustion-chlorination process involves burning the fuel elements in oxygen at 700 to $900^{\circ} \mathrm{C}$ and then chlorinating the uranium and niobium oxide products with 15 vol $\% \mathrm{CCl}_{4}-85$ vol $\% \mathrm{Cl}_{2}$ at $500^{\circ} \mathrm{C}$. The volatilized uranium and niobium chlorides are collected at room temperature and then separated by selective volatilization of niobium chloride by controlled heating to $400^{\circ} \mathrm{C}$.

Uranium recovery is quantitative, and less than $1 \%$ of the niobium remains with the uranium.

Corrosion rates for nickel or high-nickel alloys are expected to average about $0.5 \mathrm{mil} / \mathrm{month}$ through the cycle. The combustion-chlorination process should be reducible to large scale practice because the reactions proceed readily, and the corrosion problems are minor.

In the direct chlorination process, rough-crushed Rover fuel is treated with chlorinating and mixed chlorinatingoxidizing gases at $800^{\circ} \mathrm{C}$. Uranium and niobium chlorides volatilize and are separated as in the combustion-chlorination process. Uranium recoveries are greater than $99 \%$. About $40 \%$ of the graphite burns. Corrosion rates are excessive, more than $1 \mathrm{in./month} \mathrm{for} \mathrm{metal} \mathrm{containers.} \mathrm{Consequently,} \mathrm{direct}$ chlorination is not presently reducible to large-scale practice. 


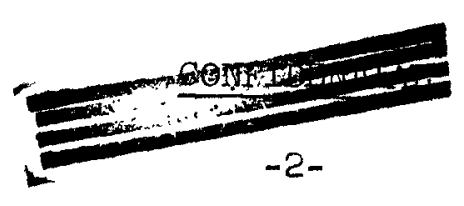

\section{INTRODUCTION}

The purpose of this work was to investigate the use of chlorination and chloride volatility methods for recovering uranium from spent graphitebase nuclear fuels. An efficient and simple process, preferably one in which common metals can be used as construction material, is desired.

A particularly important graphite-base fuel from which uranium must be recovered in the near future is the Rover fuel used in nuclear rocket research. The early Rover fuels, the KIWI A and B fuels, have a graphite matrix which is impregnated with uranium carbide. ${ }^{1,2}$ The work described in this report was performed with the KINI $B-I B$ fuel element, which is described in detail in reference 2. In later versions of the Rover fuel element, the use of uranium carbide particles, coated with pyrolytic graphite and dispersed through the graphite matrix, is planned. This modification is not expected to affect the combustion-chlorination process described below, but it will probably make it impossible to recover uranium by direct chlorination of the fuel element, the second process described in this work. Both the impregnated and coated-particle types of Rover fuels have cooling channels lined with niobium carbide. During manufacture of impregnated fuels, up to $5 \%$ of the uranium diffuses into the niobium carbide liner. The use of niobium in Rover fuel presents exceptionally troublesome chemical problems in aqueous solutions, and the presence of coated particles adds to the complexities. 3,4 Therefore, there is considerable incentive for the investigation of advanced processing methods such as chloride-volatility, either as an independent method or as a head-end step for aqueous or fluoride volatility decontamination methods. Thus a conventional solvent extraction processing plant could process Rover fuel by the addition of combustion-chloride volatility equipment for headend processing.

The more promising of the chloride volatility processes studied involves high-temperature, gas-phase chlorination of the metal oxide ash produced by burning the fuel in oxygen (most of the graphite is converted to $\left.\mathrm{CO}_{2}\right)$. Quantitative recovery of uranium is achieved under conditions leading to corrosion rates of $1 \mathrm{mil} / \mathrm{month}$ or less. For Rover fuel, which 
contains about $18 \%$ uranium and $13 \%$ niobium, the combustion ash consists of about $44 \%$ uranium and $33 \%$ niobium. Simple methods of making practically quantitative separation of the chlorides of uranium and niobium were developed. In studies of the direct chlorination and volatilization of uranium from impregnated graphite matrix fuels, near-quantitative recovery of uranium was achieved, but the conditions required appear too drastic for containment of the process in metallic construction materials.

Other chloride volatility methods have been reported for recovering uranium from nuclear fuels containing zirconium, niobium, molybdenum, aluminum, and iron. 5 An apparatus, called "The Torrefactor," is being built to demonstrate, on a large laboratory scale, the reprocessing of all these fuel types, as well as the processes for graphite fuels described in this work. Other processes being investigated for recovering uranium from Rover and other graphite-matrix fuels include combustion-hydrofluorination or combustion-fluorination, ${ }^{6}$ combustion followed by acid dissolution, disintegration-leaching, and grinding-leaching. 3,4 A chloride volatility process is used in the industrial separation of niobium pentachloride from other chlorides by vapor-liquid distillation. 7

Analyses were performed by W. R. Laing, G. R. Wilson, H. W. Dunn, E. I. Wyatt and co-workers of the Analytical Chemistry Division. Corrosion tests were planned by W. E. Clark of the Chemical Technology Division and performed by L. Rice and co-workers of the Reactor Chemistry Division.

\section{FLOWSHEETS}

2.1 Discussion of the Combustion-Chlorination Selective Volatilization Procedure

\subsubsection{Basic Steps}

The combustion-chlorination-selective volatilization process (Fig. I and Table I) involves five operations requiring a total time of about 9 $\mathrm{hr}$ : burning the fuel elements; chlorinating the uranium and niobium oxide products, with volatilization of uranium and niobium chlorides; collecting of the chlorides at ambient temperature; separating the chlorides by the 


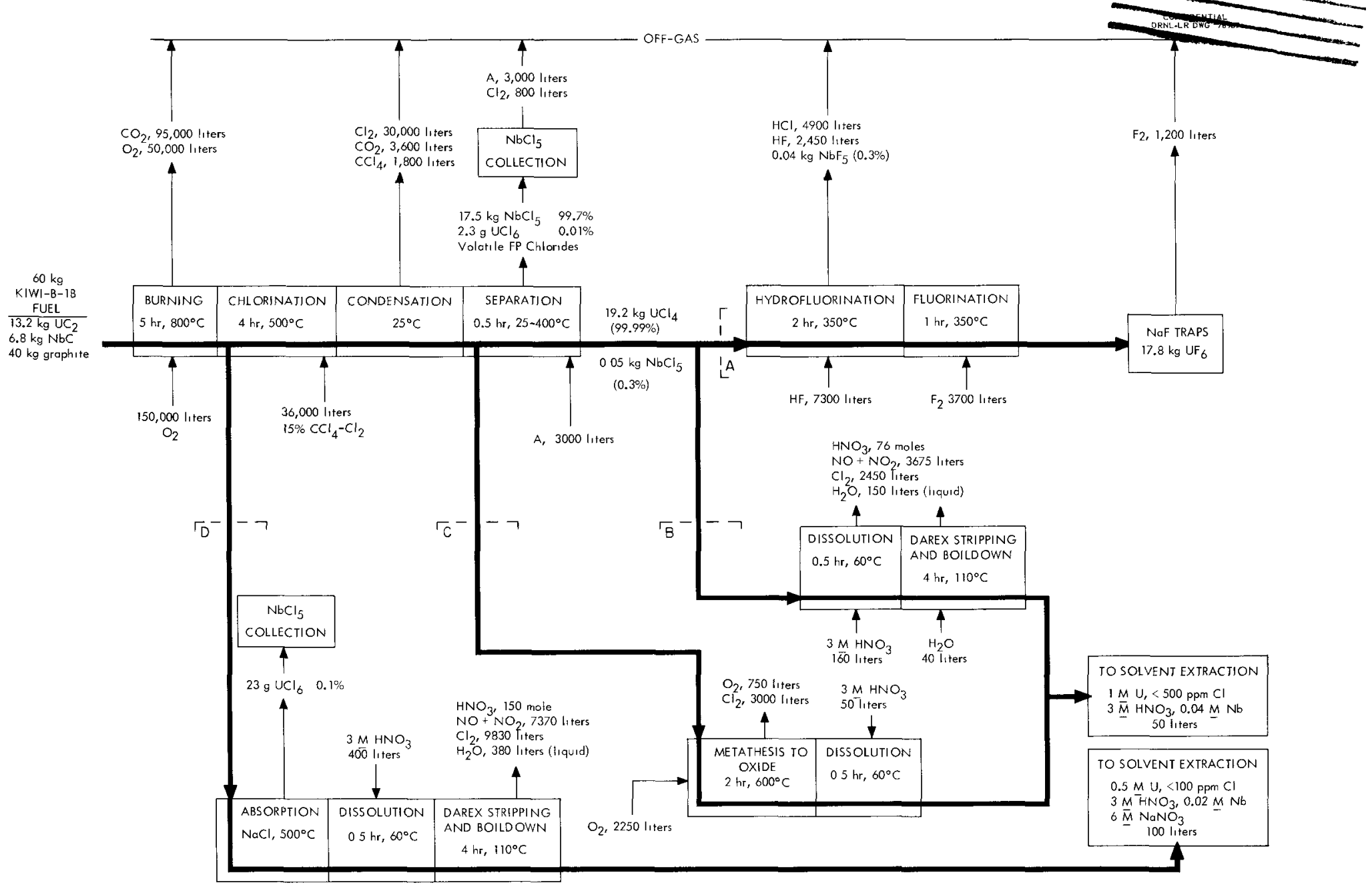

Fig. 1. Combustion-Chlorination Head-End Treatments for Four Subsequent Treatments: (A) Fluorination to $\mathrm{UF}_{6}$, (B) Aqueous Chloride Removal and Solvent Extraction, (C) Aqueous Solvent Extraction, and (D) Sorption of Uranium Chlorides on Sodium Chloride Before Aqueous Chloride Removal and Solvent Extraction. A 50\% excess of all reagents was used. 
Table 1. Data for the Chlorination of Rover-Fuel Combustion Ash in $15 \% \mathrm{CCI}_{4}--85 \% \mathrm{Cl}_{2}$

\begin{tabular}{|c|c|c|c|c|c|c|c|}
\hline \multirow[b]{3}{*}{ Run No. } & \multicolumn{2}{|c|}{$\begin{array}{l}\text { Weight of Combustion } \\
\text { Ash or Intact Fuel }\end{array}$} & \multicolumn{2}{|c|}{$\begin{array}{l}\text { Uranium-Niobium } \\
\text { Separation Step }\end{array}$} & \multicolumn{3}{|c|}{ Results $(\%)$} \\
\hline & Element & Chlorination Step & Time & & & & Non-volatile \\
\hline & (g) & Time $(\mathrm{hr}) \mathrm{T}\left({ }^{\circ} \mathrm{C}\right)^{2}$ & (hr) & $\mathrm{T}\left({ }^{\mathrm{O}} \mathrm{C}\right)$ & $\overline{\mathrm{U}}$ & $\overline{\mathrm{ND}}$ & $\begin{array}{ll}\mathrm{U} & \mathrm{Nb}\end{array}$ \\
\hline
\end{tabular}

(a) Followed by Selective Volatilization of $\mathrm{NbCl}_{5}$ in a Stream of Argon

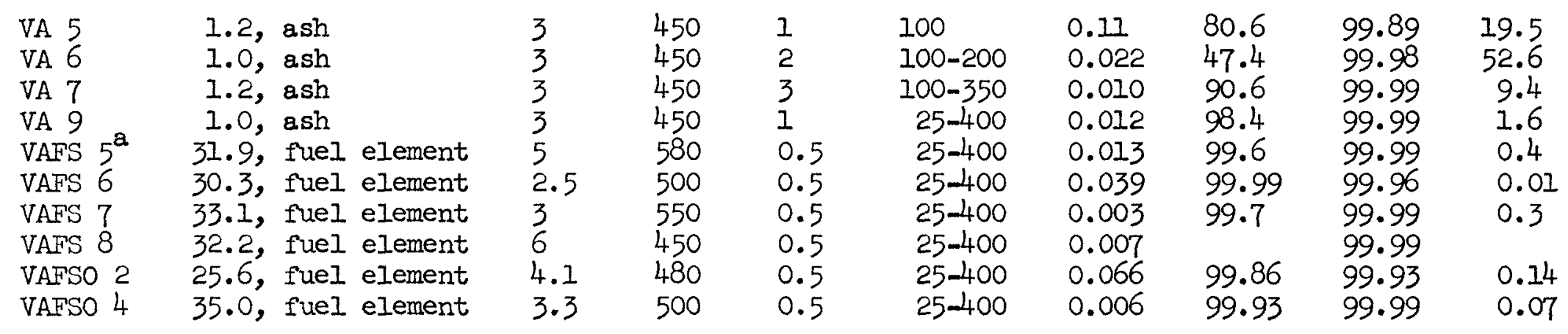

(b) Using an $\mathrm{NaCl} B e d$ to Collect Uranium Chloride

\begin{tabular}{|c|c|c|c|c|c|c|c|c|c|}
\hline $\begin{array}{l}\text { VA } 8 \\
\text { VAFS } 2 \\
\text { VAFS } 3 b \\
\text { VAFS } 4 b\end{array}$ & $\begin{array}{l}1.1 \\
32.2 \\
37.0 \\
31.1\end{array}$ & $\begin{array}{l}\text { ash } \\
\text { fuel element } \\
\text { fuel element } \\
\text { fuel element }\end{array}$ & $\begin{array}{l}4 \cdot 5 \\
6 \\
\frac{5}{6} \cdot 5\end{array}$ & $\begin{array}{l}450 \\
450 \\
450 \\
450\end{array}$ & $\begin{array}{l}450 \\
450 \\
500 \\
300-500\end{array}$ & $\begin{array}{l}0.14 \\
0.25 \\
2.12 \\
0.14\end{array}$ & $\begin{array}{l}99.8 \\
99.6 \\
99.7 \\
92.0\end{array}$ & $\begin{array}{l}99.87 \\
99.75 \\
97.88 \\
99.86\end{array}$ & $\begin{array}{l}0.2 \\
0.4 \\
0.3 \\
8.0\end{array}$ \\
\hline
\end{tabular}

In this and subsequent runs, $98 \% \mathrm{H}_{2} \mathrm{SO}_{4}$ was added to the $\mathrm{CCl}_{4}$ bubbler.

$\mathrm{b}$ Vertical salt beds; plugging occurred below $500^{\circ} \mathrm{C}$. 
selective volatilization of niobium pentachloride or oxychloride; and collecting of the niobium chloride. Collection of the mixed uranium and niobium chlorides and of the separated niobium pentachloride is carried out simultaneously with the chlorination and separation steps, respectively.

Pure oxygen is used in the burning step, and carbon dioxide and nonvolatile uranium and niobium oxides are produced. About $5 \mathrm{hr}$ at $800^{\circ} \mathrm{C}$ is required. (The burning of the graphite is discussed in detail elsewhere.) 6,8 Chlorinating the uranium and niobium oxides to produce volatile chlorides requires about $3 \mathrm{hr}$ at $500^{\circ} \mathrm{C}$ in $15 \% \mathrm{CCl}_{4}-85 \% \mathrm{CI}_{2}$. The burning and the chlorinating are quantitative, and nothing remains in the reactor with unirradiated specimens. These operations are conducted in a single vessel made of nickel or high nickel alloys. Laboratory corrosion tests (see $\mathrm{Sec}$ 5) indicate corrosion rates as low as 0.0 and $1 \mathrm{mil} / \mathrm{month}$ during burning and chlorination, respectively, and $0.2 \mathrm{mil} / \mathrm{month}$ in sequential operation. (The oxide skin on the reactor protects it from attack by chlorinating agents.) An occasional flushing of the reactor, perhaps with water, would be necessary to remove nonvolatile fission products.

The volatilized chlorides are condensed as solids in a second vessel at room temperature. The $\mathrm{Cl}_{2}, \mathrm{CO}_{2}$, and $\mathrm{CCl}_{4}$ off-gases pass through this vessel for disposal or recycle of $\mathrm{Cl}_{2}$ and $\mathrm{CCl}_{4}$. The uranium and niobium chlorides are separated rapidly by raising the temperature to $400^{\circ} \mathrm{C}$ over a $0.5-\mathrm{hr}$ period in order to volatilize niobium chloride in a stream of inert gas. About $0.01 \%$ of the uranium is lost by volatilization with the niobium, and the rest remains as nonvolatile uranium tetrachloride, which can be converted to uranium hexafluoride [route (a), Fig. 1] or dissolved in water or nitric acid in preparation for chloride removal and subsequent solvent extraction [route (b), Fig. 1]. These routes are discussed in the next subsection. The volatilized niobium chloride is condensed in a third vessel at room temperature. The niobium chloride might be removed by dissolving it in potassium fluoride solution or hydrofluoric acid, or perhaps by melting (m.p. of pure $\mathrm{NbCl}_{5}, 194^{\circ} \mathrm{C}$ ) and allowing it to flow out as a liquid. Several of the more important fission products, such as zirconium, niobium, and molybdenum have volatile chlorides that should follow the niobium chloride. 
It is important in the chlorination and separation steps to keep oxygen-containing impurities, such as water, out of the system, because such chemicals lead to the production of nonvolatile niobium oxide.

Corrosion in the collection and separation steps should be relatively minor compared with corrosion in the burning and chlorination steps. However, either hydrogen fluoride and fluorine or water must be introduced to further process the uranium chloride by routes (a) or (b), respectively. In elther case, the corrosion of materials such as nickel or Nichrome $V$ should be low, and Haynes 25 should serve well as a collection vessel in preparation for route (b) (see Sec 5).

\subsubsection{Routes that May Be Taken After the Chlorination Step}

Details of the Fluoride Volatility process [route (a), Fig. I] and the Darex process [route (b)j are reported elsewhere. 9,10 The volatilized uranium and nioblum chlorides from the chlorination step can also be separated at about $500^{\circ} \mathrm{C}$ by passage through a sodium chloride bed, which retains all the uranium chlorides but less than $1 \%$ of the niobium chlorides [Fig. $1(\mathrm{~d})$ and Table $1(\mathrm{~b})$ ]. The bed is dissolved in nitric acid and further processed by procedures developed in the Darex process. The problems of sintering and plugging attending the use of salt beds at high temperatures, particularly when heavily loaded, makes the use of this procedure more attractive as a cleanup or safety measure for route (a) of Fig. 1, rather than as a method of uranium recovery. Other disadvantages that attend the use of a salt bed are the need for the removal of large amounts of chloride from and the inclusion of large amounts of sodium nitrate in the solvent extraction feed $[$ Fig. I (d) $]$.

The gas-phase removal of chloride from the $\mathrm{UCl}_{4}$, followed by $\mathrm{HNO}_{3}$ dissolution of the resulting oxide [Fig. 1 (c) and Table 2) appears to offer the advantages of simplicity and smaller amounts of nitrate waste over the previously developed aqueous (Darex) chloride removal process. of several variations in metathesis reagents and temperatures tried, oxygen at $600^{\circ} \mathrm{C}$ appeared most attractive. Oxygen causes little corrosion, even at $800^{\circ} \mathrm{C}$ (Sec 5), and reduces the chloride content, based on $0.1 \underline{M}$ uranium solutions, to levels comparable to those obtained in the Darex chloride-removal process. 

Table 2. Chlorination of Rover Fuel Combustion Ash in $15 \% \mathrm{CCl}_{4}-\mathrm{Cl}_{2}{ }^{\text {a }}$
at $500^{\circ} \mathrm{C}$ Followed by Chloride Removal in Oxygen at $600^{\circ} \mathrm{C}{ }^{-1}$

\begin{tabular}{|c|c|c|c|c|c|c|}
\hline \multirow[b]{3}{*}{ Run } & \multirow{2}{*}{\multicolumn{3}{|c|}{$\begin{array}{l}\text { Chloride } \begin{array}{c}\text { Results ( } \% \text { of } \\
\text { Nonvolatile }\end{array} \\
\text { Removal volatile in Argon } \\
\text { Time }\end{array}$}} & $\begin{array}{l}\text { olatile } \\
\text { hlorides }\end{array}$ & & \multirow{3}{*}{$\begin{array}{l}\text { Concentration of } \\
\text { Chloride in } 0.1 \mathrm{M} \\
\text { U Product } \\
\text { (ppm) }\end{array}$} \\
\hline & & & & \multicolumn{2}{|c|}{ Nonvolatile } & \\
\hline & $(h r)$ & $\mathrm{U}$ & $\overline{N b}$ & $\mathrm{U}$ & $\mathrm{Nb}$ & \\
\hline VAFSO 1 & 2 & 0.06 & 99.9 & 99.94 & 0.1 & 77 \\
\hline VAFSO 2 & $I$ & 0.003 & 99.9 & 99.997 & 0.1 & 84 \\
\hline VAFSO 3 & 5 & 0.04 & 99.9 & 99.96 & 0.1 & $<38$ \\
\hline
\end{tabular}

a $\mathrm{All}$ gas mixtures reported in this report are on a volume-percentage basis.

\subsubsection{Possibilities for Decontaminating the Uranium}

The burning, chlorination, condensation, and separation procedures outlined in Fig. I, with little modification, might, in themselves, without the further treatments $a, b, c$, or $d$, lead to the efficient separation of fission products as well as niobium from the uranium chloride product. Demonstrations with irradiated fuel are planned. The chlorination temperature of $500^{\circ} \mathrm{C}$ is needed only to obtain rapid reaction, not for the volatilization of uranium chlorides. The uranium and niobium chlorides could be passed in a stream of chlorine through a chamber at about $300^{\circ} \mathrm{C}$ to remove the fission products that volatilized during chlorination at $500^{\circ} \mathrm{C}$ but which are not volatile at $300^{\circ} \mathrm{C}$. Subsequent treatment of the solid chlorides, after condensations, with an inert gas stream at 400 to $500^{\circ} \mathrm{C}$ should remove by volatilization the fission products chlorides that were volatile enough to pass through the $300^{\circ} \mathrm{C}$ chamber.

\subsection{Discussion of the Direct Chlorination Process (Not Preceded by Burming in Oxygen)}

The direct chlorination process (Fig. 2 and Table 3) involves the treatment of ground or rough-crushed graphite fuel at $800^{\circ} \mathrm{C}$ with a series of four chlorinating reagents and requires a total time of about $9 \mathrm{hr}$. Collection of the mixed uranium and niobium chlorides and selective revolatilization of niobium chloride is performed as show in Fig. 1. 


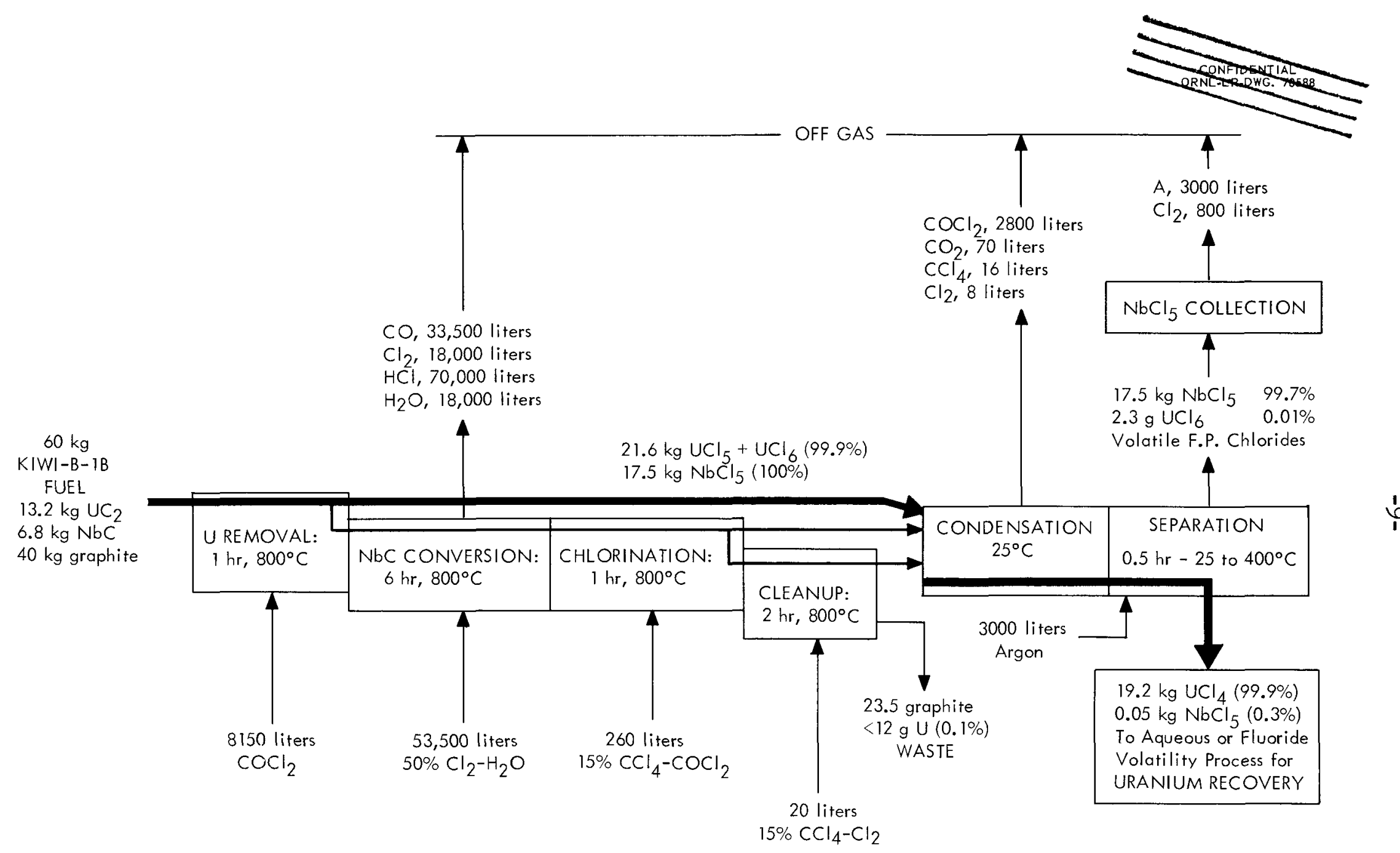

Fig. 2. Direct Chlorination Head-End Treaiment for Fluoride Volatility or Darex--Solvent Extraction

Process. A 50\% excess of all reajents was useà. 
Table 3. Recovery of Uranium from Crushed Rover Fuel (KIVI-B-1B) by Direct Chlorination at $800^{\circ} \mathrm{C}$.

Treatments: $1 \mathrm{hr}, \mathrm{COCl}_{2} ; 6 \mathrm{hr}, 50 \% \mathrm{Cl}_{2}-\mathrm{H}_{2} \mathrm{O} ; 1 \mathrm{hr} 15 \% \mathrm{CCl}_{4}-\mathrm{COCl}_{4}$; $2 \mathrm{hr}, 15 \% \mathrm{CCl}_{4}-\mathrm{Cl}_{2}$

\begin{tabular}{lcccc}
\hline & & \multicolumn{3}{c}{ Percentage of Uranium: } \\
\cline { 3 - 5 } Run & Mesh Size & Volatile & $\begin{array}{c}\text { Leachable in } \\
3 \mathrm{M} \mathrm{HNO}_{3}\end{array}$ & $\begin{array}{c}\text { Lost to } \\
\text { Graphite }\end{array}$ \\
\hline 1 & $4-12$ & 99.91 & 0.011 & 0.083 \\
2 & $\mathrm{RC}^{\mathrm{a}}$ & 99.93 & 0.008 & 0.066 \\
\hline
\end{tabular}

a Rough crushed; fuel channels exposed.

Over $95 \%$ of the uranium and part of the niobium, estimated at $50 \%$ for flowsheet calculations, is removed in a 1-hr treatment with phosgene gas at $800^{\circ} \mathrm{C}$. Mixed chlorine--carbon tetrachloride gas may be used, but the rate of reaction with this reagent is lower. The remaining niobium is converted to the pentoxide by a 6-hr treatment with $50 \% \mathrm{Cl}_{2}--\mathrm{H}_{2} \mathrm{O}$ at $800^{\circ} \mathrm{C}$. This step is actually a slow "burning" operation, and $40 \%$ of the carbon is also converted to the oxide (carbon monoxide was assumed for flowsheet calculations). Any uranium that had been trapped in the niobium carbide is also converted to oxide. This uranium oxide is chlorinated to $\mathrm{UCl}_{5}$ and $\mathrm{UCl}_{6}$ and volatilized by a l-hr treatment at $800^{\circ} \mathrm{C}$ with $15 \% \mathrm{CCl}_{4}-85 \%$ $\mathrm{COCl}_{2} \cdot$ This mixture is preferred because the production of stable and less-volatile uranyl chloride is thereby avoided. A further treatmert for $2 \mathrm{hr}$ at $800^{\circ} \mathrm{C}$ with $15 \% \mathrm{CCl}_{4}-85 \% \mathrm{Cl}_{2}$ converts nearly all the remaining uranium to volatile pentavalent and hexavalent chlorides. Uranium remaining in the graphite amounts to less than $0.1 \%$, with $10 \%$ of this 10 ss recoverable by leaching the graphite in dilute, hot nitric acid. The moisture-containing off-gas from the second chlorination step, the niobium carbide conversion, has to be routed around the vessels that are used to collect and separate uranium and niobium chloride from the exit gases from the other three steps, because moisture would convert the uranium and niobium chlorides to oxides and thereby prevent the subsequent separation of niobium by volatilization as the pentachloride or oxychloride. Corrosion studies indicate that (Sec 5) the reactor for the direct-chlorination process must be made of a ceramic in order to be sufficiently corrosion resistant, although the condensation, 
separation and niobium chloride collection could all be performed in metal vessels. Consequently, it was assumed that direct chlorination is probably not practical for large scale use at the present time.

\section{CHEMISTRY OF THE CHIORINATION PROCESSES}

The major combustion products from Rover fuel are $\mathrm{U}_{3} \mathrm{O}_{8}, \mathrm{Nb}_{2} \mathrm{O}_{5}$, and $\mathrm{CO}_{2}$. Unless excess oxygen is present during burning, carbon monoxide is also produced. There is also some possibility of a rapld reaction between carbon monoxide and oxygen to produce carbon dioxide. 6

An approximate equation may be written for the chlorination of $\mathrm{U}_{3} \mathrm{O}_{8}$ with carbon tetrachloride vapor:

$\mathrm{U}_{3} \mathrm{O}_{8}+4 \mathrm{CCl}_{4} \longrightarrow 2 \mathrm{UCl}_{5}+\mathrm{UCl}_{6}+4 \mathrm{CO}_{2} \cdot$ (ref 11)

The value of $\Delta \mathrm{H}$ at $25^{\circ} \mathrm{C}$ for this reaction is only $-27 \mathrm{kcal}$ per mole of uranium. Although the reaction goes approximately as shown in Eq. (1), the instability of and the rapid rate of interconversion between higher uranium chlorides makes it impossible to define the valence state of the uranium exactly.

The vapor pressure data in Fig. 3, taken from ref 12, show the effect of the uranium valence state on the volatility of uranium chlorides. It is necessary for the vapor pressure to reach only a small fraction of 1 atm for rapid volatilization in a stream of gas or under vacuum, and the vapor pressures at the melting points are sufficient for volatilization. For example, the vapor pressure of $\mathrm{UCl}_{6}$ at $200^{\circ} \mathrm{C}$ has been measured as 32 $\mathrm{mm} \mathrm{Hg},{ }^{13}$ while the melting point of $\mathrm{UCl}_{6}$ is about $180^{\circ} \mathrm{C}$. Thus $\mathrm{UCl}_{6}, \mathrm{UCI}_{5}$, and $\mathrm{UCl}_{4}$ can be volatilized readily at temperatures above 200,300 and $550^{\circ} \mathrm{C}$, respectively.

It can be seen from the excellent separation of uranium and niobium chlorides achieved by the selective volatilization of niobium chloride in argor between room temperature and $400^{\circ} \mathrm{C}$ [Fig. 1 and Table (la)] that the decomposition of volatile higher uranium chlorides to nonvolatile uranium tetrachloride,

$\mathrm{UCI}_{6} \longrightarrow \mathrm{UCl}_{4}+\mathrm{CI}_{2}$, 


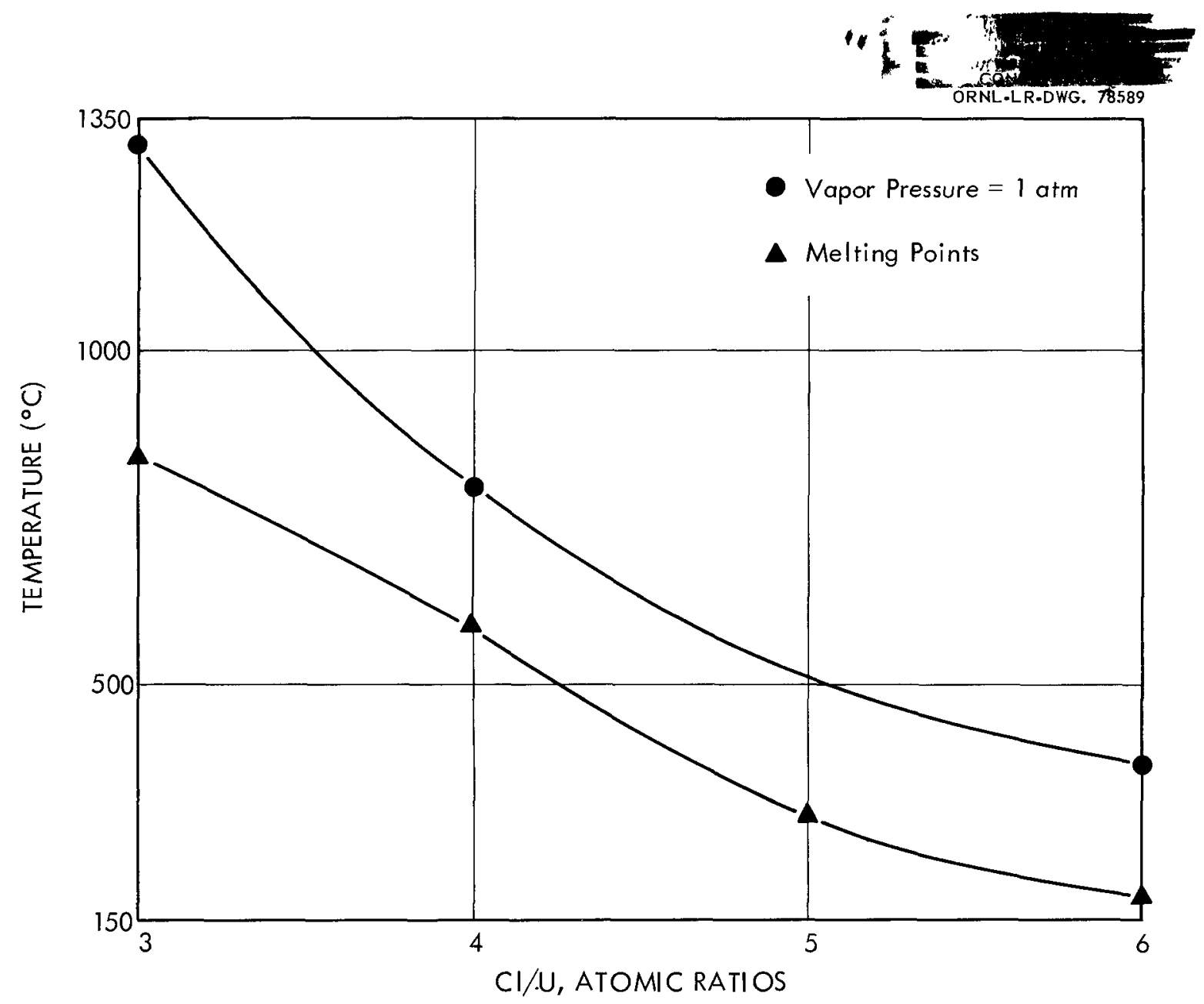

Fig. 3. Vapor Pressure and Melting Points of Uraniun Chlorides.

and

$\mathrm{UCl}_{5} \longrightarrow \mathrm{UCl}_{4}+0.5 \mathrm{Cl}_{2}$

occurs very rapidly. It is also apparent that reactions (2) and (3) would prevent the volatilization of uranium as the penta- or hexachloride at moderate temperatures such as the $500^{\circ} \mathrm{C}$ used in the chlorination step, unless a large excess of chlorine were present to drive the reactions in the reverse direction. Thus, the function of chlorine during the chlorination step is to maintain uranium in the volatile penta- or hexavalent state, thereby ensuring the complete removal of uranium from the reactor and greatly increasing the reaction rate (see Sec 4 ). 
The chlorination of niobium oxide involves the following reaction with carbon tetrachloride: ${ }^{14}$

$0.5 \mathrm{Nb}_{2} \mathrm{O}_{5}+1.25 \mathrm{CCl}_{4} \longrightarrow \mathrm{NbCl}_{5}+1.25 \mathrm{CO}_{2}$,

although some niobium oxychloride, which is very stable $e^{15}$ and is volatile at the chlorination temperature, 16,17 may form.

Only carbon tetrachloride is consumed during chlorination, and the chlorine and unused carbon tetrachloride could probably be recovered in a trap cooled by dry ice and then recycled. Efficient recovery of chlorine could lead to the recovery of more chlorine than is introduced, since part of the chlorine supplied by carbon tetrachloride (Eq. I) is released by reactions 2 and 3 during the separation step. Small amounts of carbon monoxide and phosgene are also expected in the chlorination products. $11,18,19$ The phosgene would be captured in the chlorine cold trap and should cause no problems if recycled to the chlorinator, and the carbon monoxide would pass through with the carbon dioxide.

The complex compounds $\mathrm{NaCl} \cdot \mathrm{UCl}_{4}$ and $2 \mathrm{NaCl} \cdot \mathrm{UCl}_{4}$ are known, ${ }^{20}$ and mixtures of these compounds are probably the final products obtained from the sorption of uranium chloride on a sodium chloride bed. The eutectic of these compounds, which melts below $500^{\circ} \mathrm{C}$, may cause the sintering and plugging observed in salt beds below $500^{\circ} \mathrm{C}$. Above $500^{\circ} \mathrm{C}$, diffusion through the bed is probably rapid enough to ensure the formation of complex compounds richer in sodium chloride and therefore of higher melting point. Some of the uranium captured in the sodium chloride bed probably has a valence higher than four, since the uranium-containing portion of the bed is red so long as chlorine gas flows. In the absence of chlorine, the bed color changes to the green of tetravalent uranium. A complex compound of niobium pentachloride and sodium chloride is known, 21,22 but the decomposition temperature is about $287^{\circ} \mathrm{C}$ (ref 22), and the niobium chloride cannot be captured on sodium chloride beds at temperatures as high as $400^{\circ} \mathrm{C} .23$

The gas-phase removal of chloride from uranium chloride is based on the reactions shown below, depending on whether oxygen or water vapor is used:

$3 \mathrm{UCl}_{4}+4 \mathrm{O}_{2} \longrightarrow \mathrm{U}_{3} \mathrm{O}_{3}+6 \mathrm{Cl}_{2} \quad$ (ref 24), 
or

$\mathrm{UCl}_{4}+2 \mathrm{H}_{2} \mathrm{O} \longrightarrow \mathrm{UO}_{2}+4 \mathrm{HCl}$.

Some of the stable intermediate compound $\mathrm{UO}_{2} \mathrm{Cl}_{2}$ was produced by reaction (5) at 300 to $500^{\circ} \mathrm{C}$, and good chloride removal could not be achieved in a practical time period at these temperatures. The hydrolysis reaction (6) proceeds rapidly in moist air even at room temperature but the moist chloride off-gas from the reaction can cause excessive corrosion, particularly at low temperatures and on alloys containing large amounts of nickel. Therefore, oxygen rather than water was used to achieve chloride removal (Fig. 1). In practice, some inert diluent gas should be mixed with the oxygen to prevent uranium volatilization through the reverse of reactions (2) and (3) when chlorine is liberated rapidly at the beginning of the chloride removal operation.

The direct chlorination process involves chemical reactions very similar to those already discussed. However, the niobium carbide conversion step involves reactions which, for the flowsheet calculations, were assumed to proceed as follows:

$\mathrm{NbC}+3.5 \mathrm{H}_{2} \mathrm{O}+3.5 \mathrm{Cl}_{2} \longrightarrow 0.5 \mathrm{Nb}_{2} \mathrm{O}_{5}+7 \mathrm{HCl}+\mathrm{CO}$, $\mathrm{C}+\mathrm{H}_{2} \mathrm{O}+\mathrm{Cl}_{2} \longrightarrow 2 \mathrm{HCl}+\mathrm{CO}$.

The treatment of niobium carbide with oxygen-phosgene or oxygen-chlorine mixtures converts most of the carbide to the volatile oxychloride: $\mathrm{NbC}+\mathrm{O}_{2}+1.5 \mathrm{COCl}_{2} \longrightarrow \mathrm{NbOCl}_{3}+2.5 \mathrm{CO}$.

Reaction (9) proceeds slowly unless the reagent gas contains $40 \% \mathrm{O}_{2}$, enough to satisfy the stoichiometry of the reaction and prevent a buildup of carbon on the reaction surface. At $700^{\circ} \mathrm{C}$ or higher, niobium carbide ignites and burns rapidly in $40 \% \mathrm{O}_{2}-\mathrm{COCl}_{2}$. Only a small amount of nonvolatile $\mathrm{Nb}_{2} \mathrm{O}_{5}$ forms, and none forms in the presence of excess carbon. Reaction (7) was chosen for the process (Fig. 2) because, although the niobium reacts and is volatilized from the graphite surface, it hydrolyzes to form nonvolatile $\mathrm{Nb}_{2} \mathrm{O}_{5}$ in the vapor phase and remains in the reactor. If niobium were volatilized from the reactor during the $\mathrm{NbC}$ conversions, two waste streams containing niobium would result, since the off-gas from the niobium carbide conversion cannot be passed through the chloride collector. Passage of 
this off-gas, containing moisture or oxygen, through the chloride collector would convert uranium and niobium chlorides to oxides and thereby prevent the separation of niobium chloride by volatilization. When either oxygen or water vapor was mixed with chlorine or phosgene to effect the conversion of niobium carbide to either oxide or oxychloride, it was impossible to avoid the underirable "burning" of carbon, as illustrated in Eqs. (8) and (9), since the complete conversion of niobium carbide could not be achieved without attacking and volatilizing the carbon arising from niobium carbide. Attempts to completely convert the niobium carbide to oxide by hydrolysis, $\mathrm{NbC}+3.5 \mathrm{H}_{2} \mathrm{O} \longrightarrow 0.5 \mathrm{Nb}_{2} \mathrm{O}_{5}+\mathrm{CO}+3.5 \mathrm{H}_{2}$,

were unsuccessful, probably because hydrogen competes with carbon as a reducing agent at the high temperatures required for rapid hydrolysis. Incomplete conversion of the niobium carbide always resulted in excessive uranium losses.

\section{CHIORINATION EXPERIMENTS AND RESULTS \\ 4.1 Chlorination of Combustion Ash}

Studies of chlorination of combustion ash had two major objectives: (1) achievement of rapid rates at temperatures low enough for easy containment of the reagents in metal equipment, and (2) complete volatilization of the ash. Both goals were achieved by mixing chlorine in the reagent gas to maintain uranium as the volatile penta- or hexavalent chloride (see Eqs. (2) and (3), Sec 3).

The addition of 30 vol $\% \mathrm{Cl}_{2}$ to a 15 vol $\% \mathrm{CCl}_{4}--85$ vol $\% \mathrm{~N}_{2}$ gas stream increased the volatilization rate of $\mathrm{UCl}_{4}$ at $500^{\circ} \mathrm{C}$ over tenfold (Fig. 4). It was necessary to achieve rapid volatilization at about $500^{\circ} \mathrm{C}$ because uranium tetrachloride melts below $600^{\circ} \mathrm{C}$ (Fig. 3) and because corrosion rates increase rapidly in this temperature range ( $\sec 5$ ).

The chlorination and volatilization of ash (Fig. 5) did not occur as rapidly as the volatilization of $\mathrm{UCl}_{4}$ (Fig. 4), apparently because chlorination is the slower and rate-limiting step, rather than volatilization. Analysis of the residue after partial chlorination (Table 4) showed that niobium was being removed from the ash much more rapidly than uranium; 


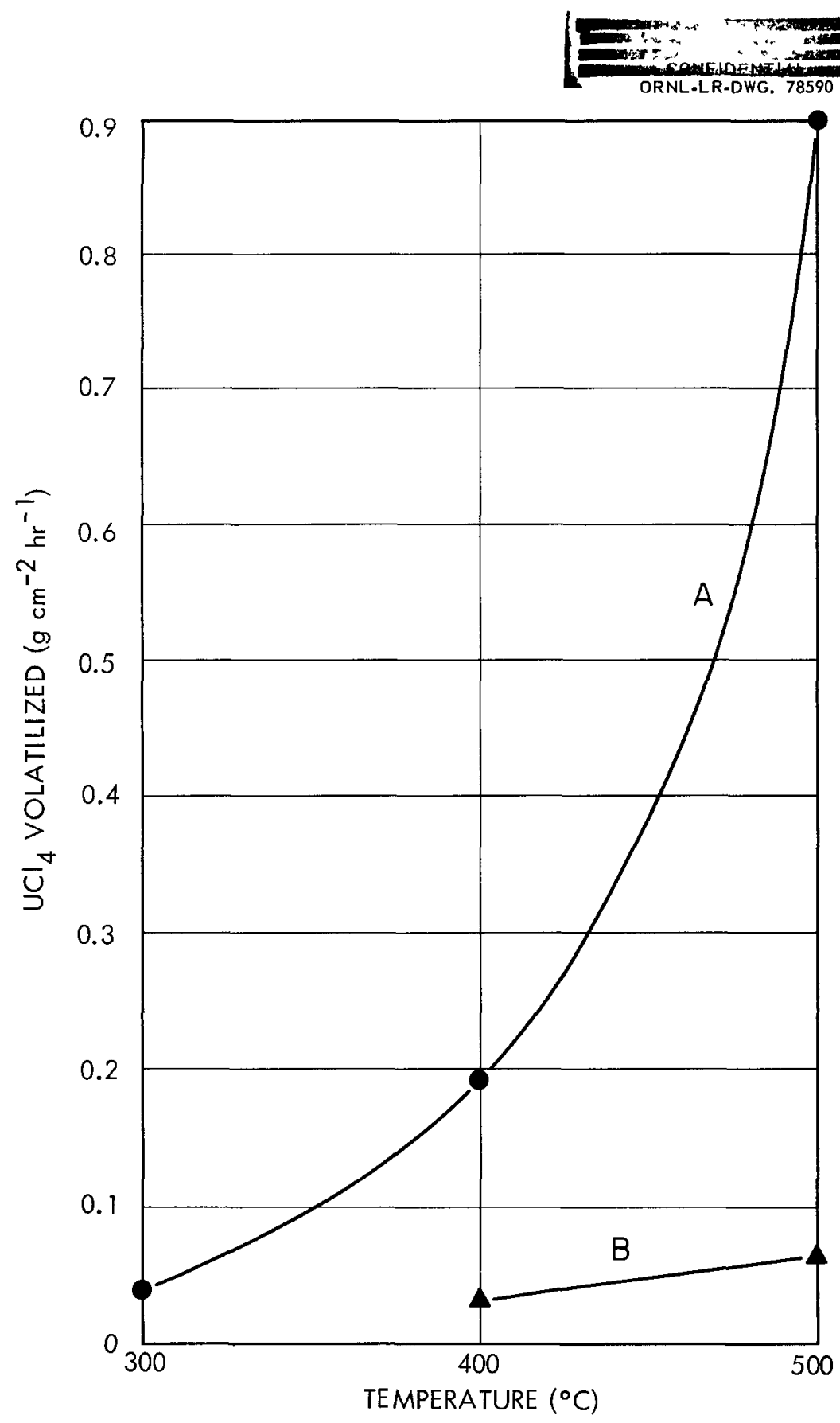

Fig. 4. Volatilization of Uranium Chloride in Flowing (A) $30 \% \mathrm{Cl}_{2}--15 \% \mathrm{CCl}_{4}--55 \% \mathrm{~N}_{2}$ and (B) $15 \% \mathrm{CCl}_{4}--85 \% \mathrm{~N}_{2}$. Flow rate, $300 \mathrm{cc} / \mathrm{min}$; inner-diameter of tube, 1 in. 


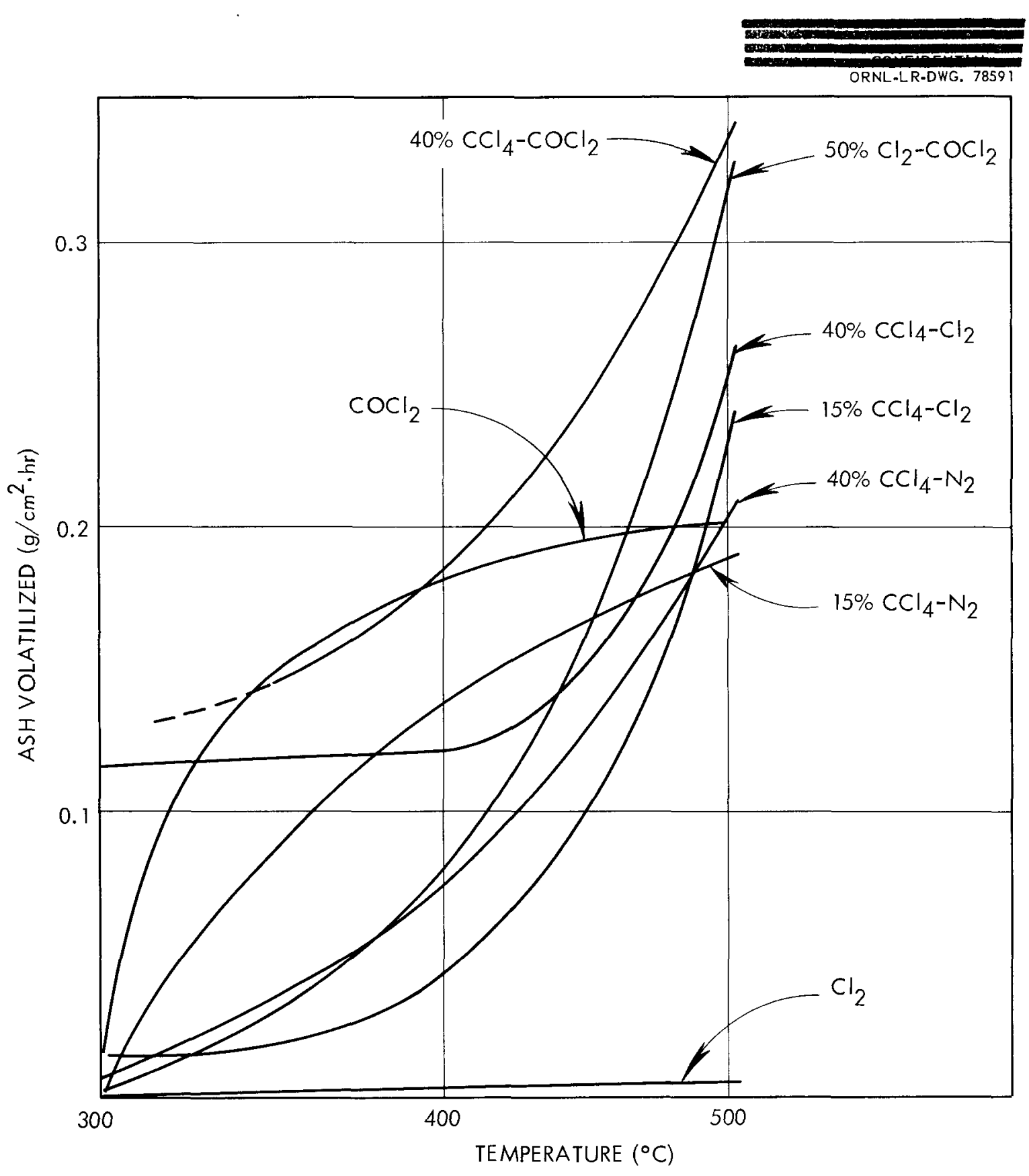

Fig. 5. Chlorination and Volatilization of GraphiteFuel Combustion Ash in Flowing Chlorinating Gas. Flow Rate, $500 \mathrm{cc} / \mathrm{min}$; tube internal diameter, 1-in.; time,30 min. 
Table 4. Chlorination of Rover Fuel Combustion Ash in Various Chlorinating Reagents and Reagent Mixtures

$$
\begin{aligned}
& \text { Temperature: } 500^{\circ} \mathrm{C} \quad \text { Ash Weight: } 0.4-0.9 \mathrm{~g} \\
& \text { Tube: I-in. ID Gas-Flow Rate: } 300 \mathrm{cc} / \mathrm{min} \\
& \text { Time: } 30 \mathrm{~min}
\end{aligned}
$$

\begin{tabular}{lclc}
\hline \multicolumn{1}{c}{ Reagent } & $\begin{array}{c}\text { U/Mb Mole Ratio } \\
\text { in Residue }\end{array}$ & \multicolumn{1}{c}{ Reagent } & $\begin{array}{c}\text { U/Nb Mole Ratio } \\
\text { in Residue }\end{array}$ \\
\hline None & 1.3 & $\mathrm{CI}_{2}$ & No reaction \\
$15 \% \mathrm{CCl}_{4}--\mathrm{N}_{2}$ & 7.6 & $\mathrm{COCl}_{2}$ & 69 \\
$40 \% \mathrm{CCl}_{4}--\mathrm{N}_{2}$ & 12 & $50 \% \mathrm{Cl}_{2}--\mathrm{COCl}_{2}$ & 6.8 \\
$40 \% \mathrm{CCl}_{4}--\mathrm{Cl}$ & 33 & $40 \% \mathrm{CCI}_{4}--\mathrm{COCI}_{2}$ & 77 \\
\hline
\end{tabular}

thus the presence of niobium oxide in the ash does not slow the chlorination reaction. Since the chlorination rate is not limited by the rate of volatilization of uranium, which depends on the partial pressure of chlorine, it appears that chlorine aids carbon tetrachloride in the chlorination of uranium oxide, since the replacement of nitrogen by chlorine in the carbon tetrachloride vapor (Fig. 5) resulted in higher chlorination rates. The highest chlorination-volatilization rates were obtained with phosgene mixed with carbon tetrachloride vapor or chlorine. Pure chlorine did not react with the ash at $500^{\circ} \mathrm{C}$. Phosgene or phosgene--carbon tetrachloride vapor probably chlorinate niobium oxide rapidly, because the residues after partial chlorination were mainly uranium salts (Table 4). Because of (1) the hazards associated with phosgene, (2) the need for the introduction of chlorine toward the end of a chlorination with phosgene to ensure complete volatilization of uranium, and (3) the simplicity of preparing a chlorine--carbon tetrachloride reagent by bubbling chlorine through liquid carbon tetrachloride, the use of chlorine--carbon tetrachloride vapor was recommended in the flowsheet (Fig. 1). Since the rates achieved with $40 \% \mathrm{CCl}_{4}--60 \% \mathrm{Cl}_{2}$ were only slightly higher than those obtained with $15 \% \mathrm{CCl}_{4}--85 \% \mathrm{Cl}_{2}$, the reagent containing $15 \% \mathrm{CCl}_{4}$ was used.

To determine the optimum temperature for chlorination, several flowsheet runs were made in which the combustion ash was chlorinated at various temperatures between 450 and $580^{\circ} \mathrm{C}$. The time required for complete reaction 
was excessive - more than $6 \mathrm{hr}$ - at temperatures less than $450^{\circ} \mathrm{C}$ and. was at a minimum of 2.5 to $3 \mathrm{hr}$ at about $500^{\circ} \mathrm{C}$. The reaction time increased at temperatures above $500^{\circ} \mathrm{C}$ because of the reduction in surface area caused by the melting of the uranium chlorides and the attendant sintering of the mixed ash--chloride residue (Fig. 6).

\subsection{Direct Chlorination of Graphite Fuels}

\subsubsection{Uncoated Fuels}

In experiments in which graphite fuel impregnated with uranium carbide, the type used in the Turret reactor, was treated with chlorine gas, it was found that a temperature of over $750^{\circ} \mathrm{C}$ was required for the rapid removal of uranium (Fig. 7). After $2 \mathrm{hr}$ at $750^{\circ} \mathrm{C}$, the graphite retained $1.5 \%$ of the total uranium. Since this was not coated graphite, the $1.5 \%$ uranium retention must be due to elther the slow diffusion of uranium compounds through the smaller graphite pores at $750^{\circ} \mathrm{C}$ or to the formation of uranyl chloride $\left(\mathrm{UO}_{2} \mathrm{Cl}_{2}\right)$ that becomes trapped in larger pores near the surface. The presence of water-soluble but nonvolatile uranium on the graphite after chlorination in experiments described below supports the latter postulate. Thus, it is necessary to use both high temperatures and reagents other than chlorine which are capable of attacking or avoiding the formation of uranyl chloride in order to achieve the rapid removal of uranium from uncoated uranium carbide--graphite fuels.

\subsubsection{Problems Presented by Fuels Coated with Niobium Carbide}

The niobium carbide coating on Rover fuel that does not contain coated fuel particles complicates the direct chlorination procedure for removing the recovering uranium, since the niobium coating must be destroyed in order to recover contained uranium. As discussed in Sec 3, it is necessary to burn a large fraction of the graphite in order to obtain the complete reaction of the niobium carbide, which can be attacked only by reagents that simultaneously burn the carbon. Should the niobium carbide coating of future Rover fuels be free of uranium, a direct chlorination process might be more attractive than at present. However, as discussed in the introduction to this report, while the use of coated fuel particles may 


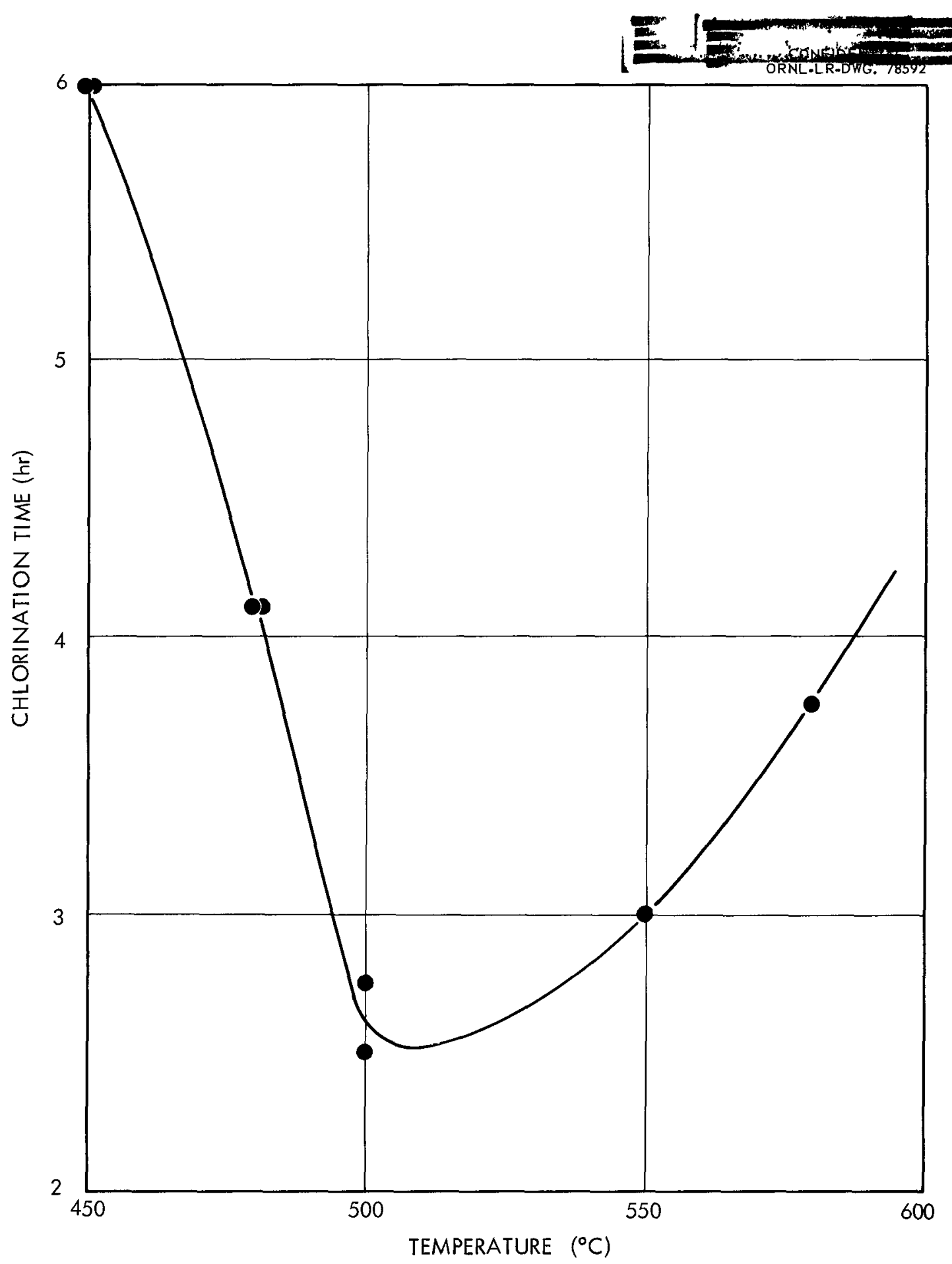

Fig. 6. Tine Required for Corplete Chlorination of Combustion Ash from 30 to 33 g Rover Fuel Rods in 15\% $\mathrm{CCl}_{4}--\mathrm{Cl}_{2}$. Flow rate, 1 liter/min; inner diameter of tube, 2 in. 


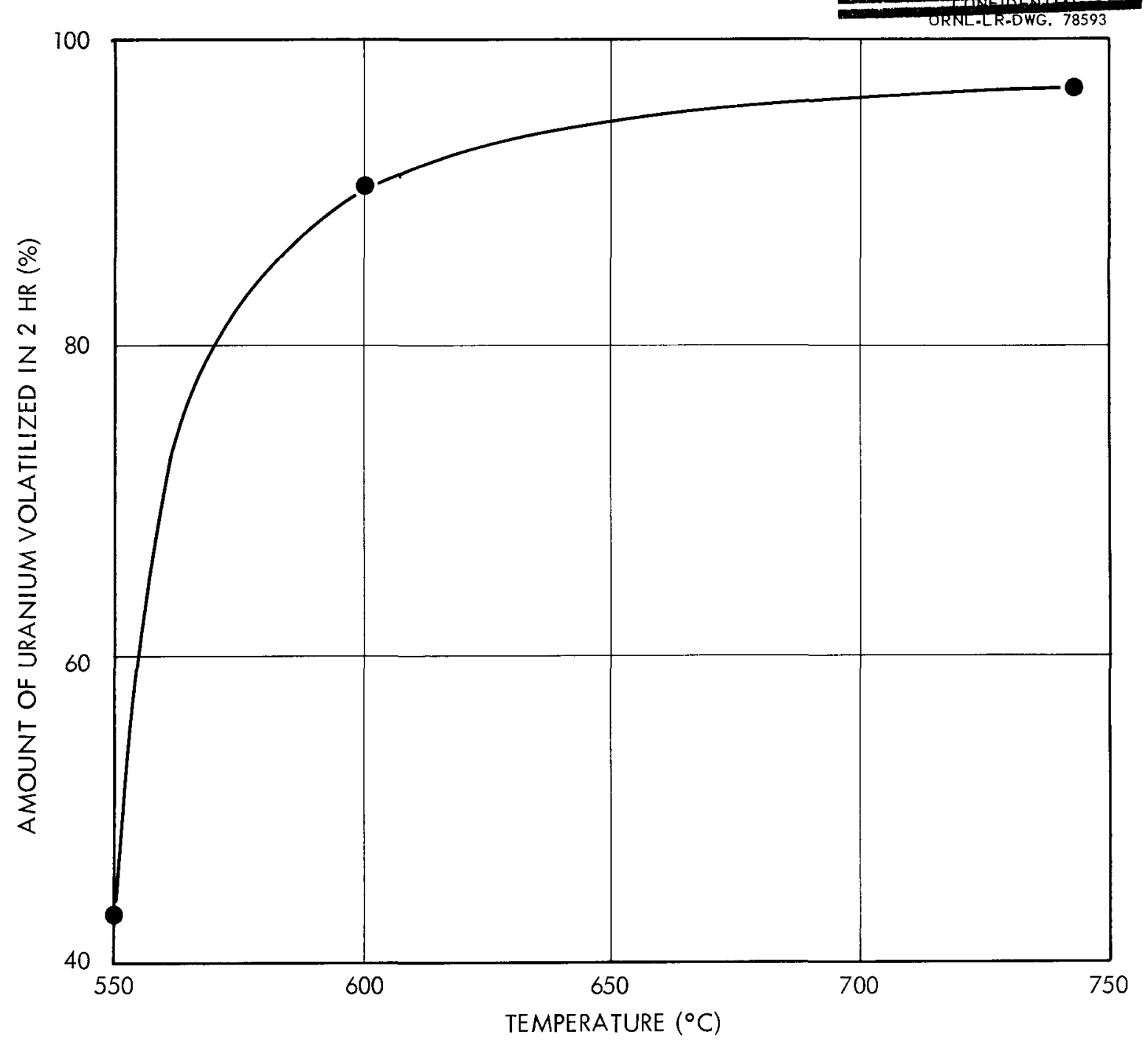

Fig. 7. Volatilization of Unanium Chloride from Turret Uraniurn Carbide--Graphite ( $7 \%$ U) Reactor Puel by Treatment with Gaseous Chlorine. 
prevent diffusion of uranium into the niobium carbide liner, it may also make it impossible to recover the uranium by direct chlorination, since this method of recovery is dependent on rapid diffusion of uranium chloride out of the fuel element.

The rate of attack of niobium carbide by hydrogen chloride, chlorine, or phosgene at 700 to $800^{\circ} \mathrm{C}$ was excessively slow. The addition of a small amount of oxygen to chlorine at $700^{\circ} \mathrm{C}$ increased the reaction rate greatly, with the maximum niobium volatilization occurring at about $50 \%$ oxygen (Table 5). The products are thought to be only nonvolatile niobium oxide and volatile niobium oxychloride. The nonvolatile niobium oxide residue did not form when the niobium carbide was in contact with graphite, and the only product was volatile niobium oxychloride. The addition of oxygen to phosgene produced a slightly different effect in that the attack on niobium carbide was relatively very slow with reagents containing less than $40 \%$ oxygen, the stoichiometric quantity required for reaction (9) (see Sec 3). At this point the niobium carbide ignited, and the rate of attack was more rapid than that for the analogous chlorine reagent.

In a series of runs in which uranium recovery was attempted by the direct chlorination of ground KIWI B-IB Rover fuel (Table 6), the recovery exceeded $99 \%$ if the preliminary treatment with mixed chlorine-oxygen was extensive enough to completely burm the niobium carbide. Variations in the length of the subsequent treatments with chlorine and chlorine--carbon tetrachloride had a minor effect on the recoveries in comparison with that of the chlorine--oxygen treatment. Raising the tenperature from 625 to $800^{\circ} \mathrm{C}$ at a $0.25-\mathrm{hr}$ contact time in $25 \% \mathrm{O}_{2}-\mathrm{Cl}_{2}$ increased the uranium recovery from 95 to $97 \%$, while the percentage of graphite weight loss increased from 17.5 to $20 \%$. About $10 \%$ of the graphite weight loss occurs through desorption of absorbed vapors, and the balance occurs through burming. Both an increase in contact time to $0.5 \mathrm{hr}$ at $800^{\circ} \mathrm{C}$ and an increase in the amount of oxygen in the chlorine from 25 to $33 \%$ improved uranium recoveries while also increasing the amount of graphite burnt.

It appears that excellent uranium recoveries are possible at $800^{\circ} \mathrm{C}$ if there is enough burning to effect a weight loss of more than $30 \%$ for 
Table 5. Data for the Chlorination of Niobium Carbide in Chlorine or Phosgene Mixed with Oxygen
Time: $1 \mathrm{hr}$
Flow: $300 \mathrm{cc} / \mathrm{min}$
Temperature: $700^{\circ} \mathrm{C}$
$\mathrm{NbC}$ wts: $\sim 0.5 \mathrm{~g}$

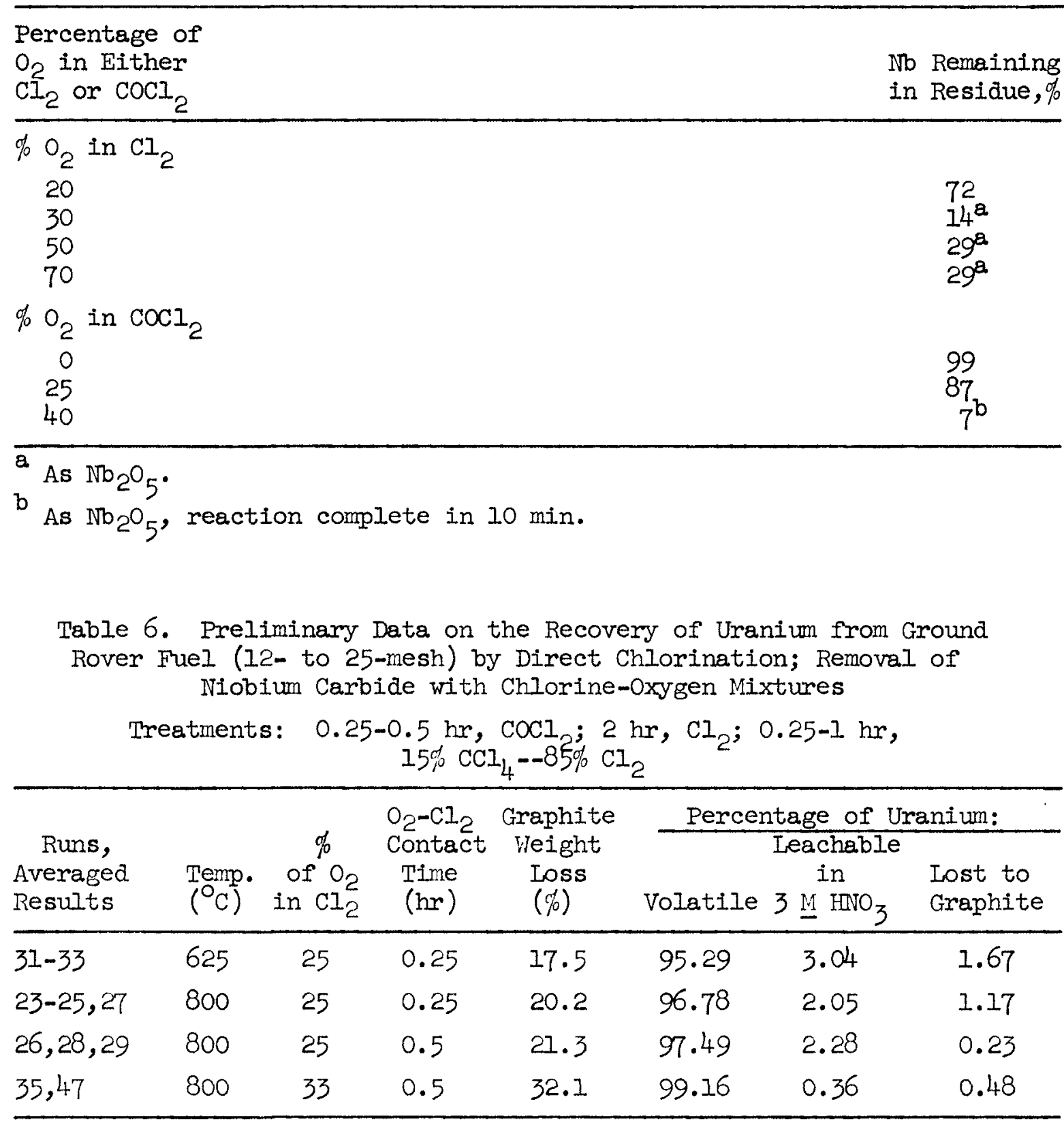

the graphite. Major disadvantages in the use of chlorine-oxygen mixtures are the rapid burning as well as the uneven burning. The fuel that contacts fresh reagent gas as it enters the reactor burns faster than fuel farther 
from the reagent inlet. Because of these disadvantages, chlorine--water vapor mixtures were also investigated. This reagent burns carbon slower at $800^{\circ} \mathrm{C}$ and thus it is easier to control the amount of graphite burning.

In the use of $50 \% \mathrm{Cl}_{2}-\mathrm{H}_{2} \mathrm{O}$, as in the case of chlorine-oxygen, the major variable affecting uranium recoveries is the completeness of the reaction with niobium carbide, as indicated by the amount of graphite burned. In a series of runs made according to the flowsheet conditions (Fig. 2) with ground (4- to 12-mesh) Rover fuel in which the temperature was varied, excellent uranium recoveries (99.9\%) were achieved at $800^{\circ} \mathrm{C}$, but the recoveries decreased regularly with temperature to less than $98 \%$ at $650^{\circ} \mathrm{C}$ (Fig. 8). Very little additional uranium was recoverable by leaching the graphite product in hot nitric acid. The recoveries are directly correlatable with the graphite weight losses, which increase from $39 \%$ at $650^{\circ} \mathrm{C}$ to $47 \%$ at $800^{\circ} \mathrm{C}$.

In similar experiments with rough-crushed Rover fuel, which was crushed only enough to break the fuel into long splinters and expose the coolant channels, the uranium recoveries were again directly correlatable with the amount of graphite burnt. However, in this case, both the uranium recoveries and the graphite weight losses were greater at 675 than at $725^{\circ} \mathrm{C}$ (Fig. 9). The same result might have occurred with the 4- to 12-mesh material (Fig. 8) without having been observed because the range between temperatures was greater in the experiments with 4- to 12-mesh particles. In either case, a temperature of about $800^{\circ} \mathrm{C}$ was needed for the best uranium recoveries. The amount of uranium recoverable by leaching the rough-crushed fuel product was also smallest for the material that had been chlorinated at $800^{\circ} \mathrm{C}$.

Since the uranium loss was still excessive (nearly 1\%) with the 4.8-hr treatment of rough-crushed fuel with $50 \% \mathrm{Cl}_{2}--\mathrm{H}_{2} \mathrm{O}$, the effect of varying the period of the treatment was studied. Uranium recoveries increased from $98.5 \%$ to more than $99.9 \%$ as the time was increased from 4 to $6 \mathrm{hr}$ (Fig. 10). The graphite weight loss also increased from 38 to 58\%, indicating that as much carbon is burned by equivalent treatments of roughcrushed fuel as with 4- to 12-mesh fuel. The amount of uranium remaining in the graphite and recoverable by leaching in dilute nitric acid decreased 


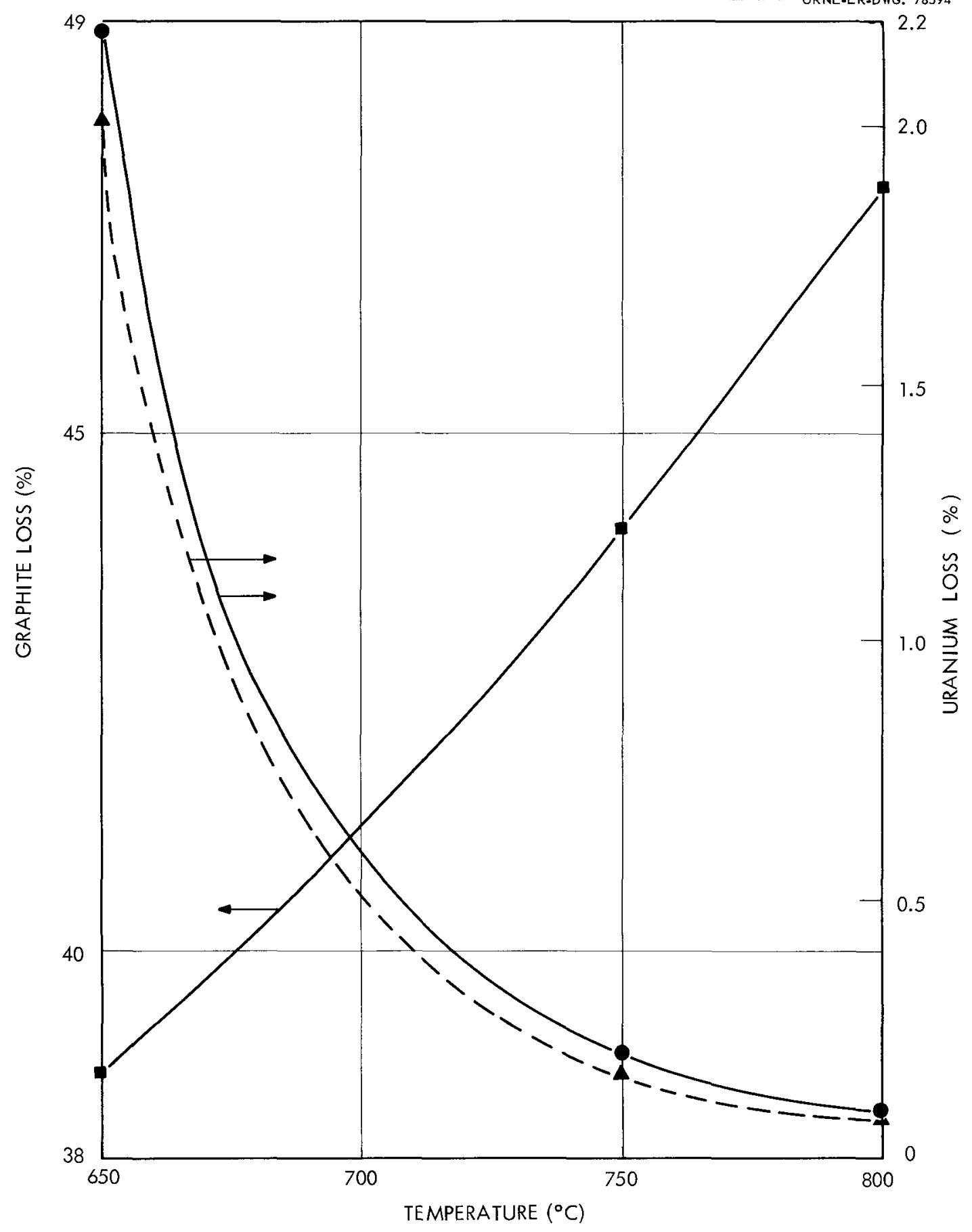

Fig. 8. Graphite Weight and Percent Uranium Losses from Ground (4-12 mesh) Rover Fuel as a Function of Temperature of Treatment in 50\% $\mathrm{Cl}_{2}-\mathrm{H}_{2} \mathrm{O}$. Treatments: I hr, COCl 2 , $6 \mathrm{hr}, 50 \% \mathrm{Cl}_{2}--\mathrm{H}_{2} \mathrm{O} ; \mathrm{I} \mathrm{hr}$, $15 \% \mathrm{CCl}_{4}--\mathrm{COCl}_{2} ; 2 \mathrm{hr}, 15 \% \mathrm{CCl}_{4}--$ $\mathrm{Cl}_{2}$. Dashed line shows the uraniun loss not recoverable by leaching in $3 \mathrm{MHNO}_{3}$. About a 10 wt $\%$ loss in graphite was caused by vapor desorption. 


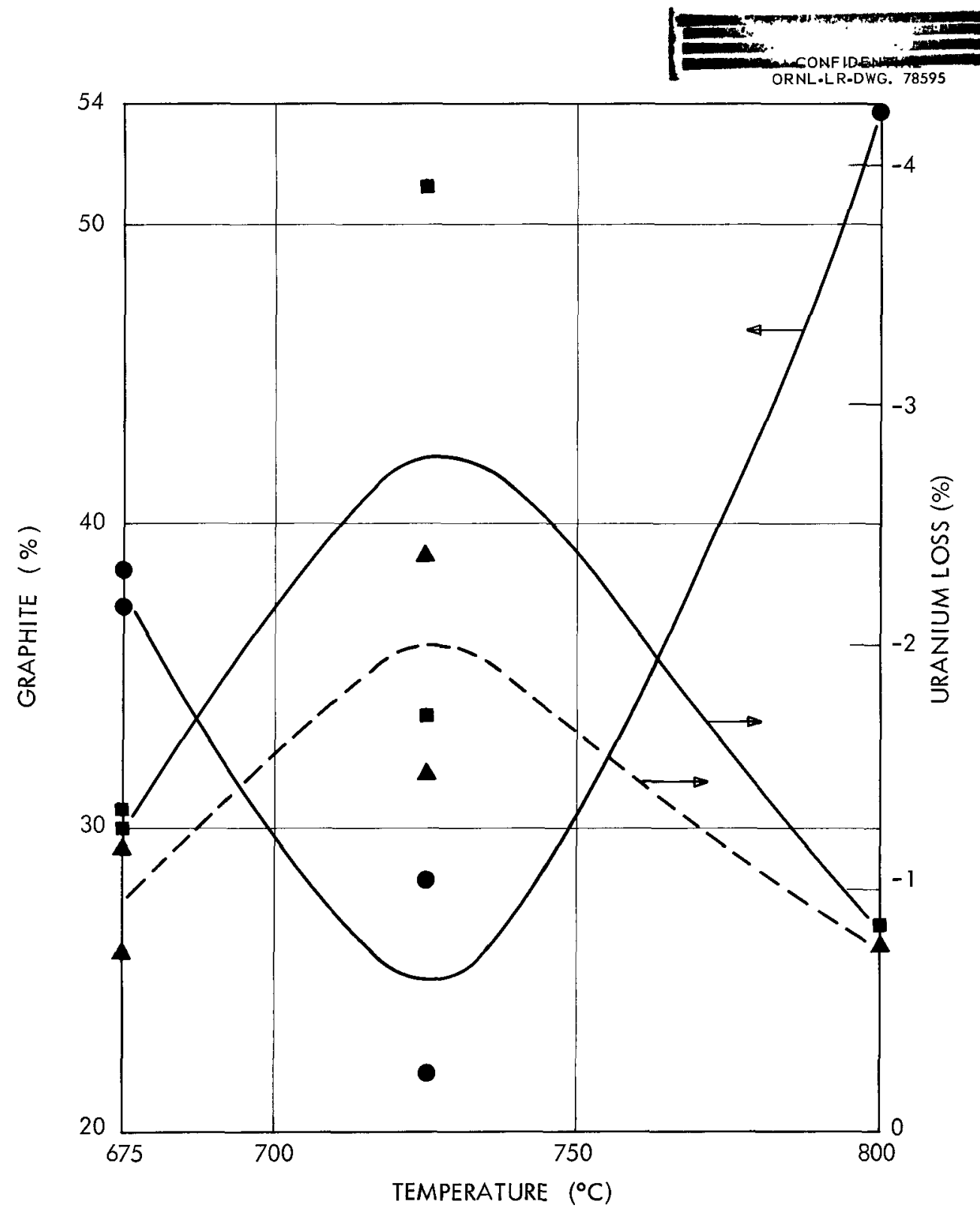

Fig. 9. Graphite Weight and Percent Uraniun Losses from Rough-Crushed Rover Fuel as a Function of Temperature of Treatment in 50\% $\mathrm{Cl}_{2}--\mathrm{H}_{2} \mathrm{O}$. Treatments: I hr, $\mathrm{COCl}_{2} ; 4.8 \mathrm{hr}, 50 \% \mathrm{Cl}_{2}-\mathrm{H}_{2} \mathrm{O}$; I hr 15\% $\mathrm{CCI}_{4}--\mathrm{COCl}_{2} ; 2 \mathrm{hr}, 15 \% \mathrm{CCI}_{4}-\mathrm{Cl}_{2}$. Dashed Iine shows uranium losses not recoverable by leaching in $3 \mathrm{M}^{2} \mathrm{INO}_{3}$. 


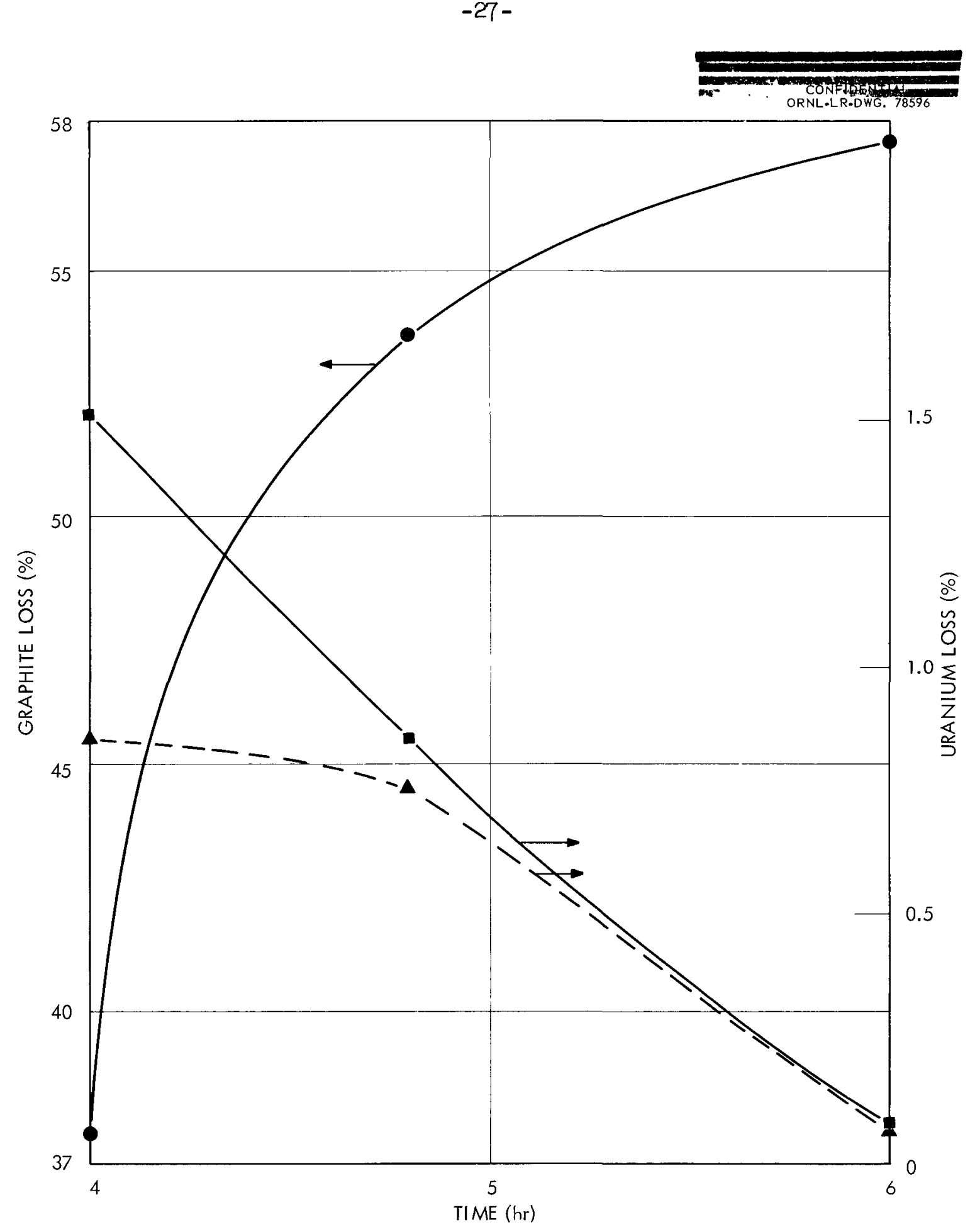

Fig. 10. Graphite Weight and Percent Uranium Iosses from

Rough-Crushed Rover Fuel as a Function of Duration of Treatment in $50 \% \mathrm{Cl}_{2}--\mathrm{H}_{2} \mathrm{O}$. Treatments: $1 \mathrm{hr}, \mathrm{COCl}_{2} ; 4-6 \mathrm{hr}, 50 \% \mathrm{Cl}_{2}-\mathrm{H}_{2} \mathrm{O}$; I hr, $15 \% \mathrm{CCl}_{4}--\mathrm{COCl}_{2} ; 2 \mathrm{hr}, 15 \% \mathrm{CCl}_{4}-\mathrm{Cl}_{2} ;$ Temperature, $8000^{\circ} \mathrm{C}$. Dashed line shows uranium loss not recoverable by leaching in 3 I. $\mathrm{HNO}_{3}$. 
from about 50\% of the total loss after the 4-hr treatment to essentially none after the 6-hr treatment.

5. DISCUSSION OF CORROSION RATES AND SUITABLE MATERIALS OF CONSTRUCTION

Corrosion tests in chlorine and carbon tetrachloride vapor indicate an activation energy of about $20 \mathrm{kcal} / \mathrm{mole}$ with all materials tested (Fig. 11). The strong dependence of corrosion rates on temperature necessitates careful wall temperature control and explains why excessive corrosion rates have sometimes been observed when wall temperatures were allowed to rise during chlorination. On the other hand, the strong dependence of corrosion rates on temperature makes the use of chlorinating agents attractive at temperatures of $500^{\circ} \mathrm{C}$ or lower for nickel or Nichrome V, or at $600^{\circ} \mathrm{C}$ for INOR-8 (INOR-8 corroded at a lower rate in chlorine than in either $\mathrm{CCI}_{4}-\mathrm{N}_{2}$ or $\mathrm{CCl}_{4}-\mathrm{Cl}_{2}$, differing in that respect from the other metals or alloys). The corrosion tests were generally run for $24 \mathrm{hr}$, but at temperatures near $700^{\circ} \mathrm{C}$, the testing period was shortened because of catastrophic corrosion rates. Brief corrosion tests with type 304 stainless steel at 600 and $625^{\circ} \mathrm{C}$ indicated corrosion rates about a hundred times faster than those observed with the best high-nickel alloys tested.

Preliminary corrosion tests were made with Haynes 25 and "A" nickel for the burning-chlorination cycle shown in Fig. 1 (data shown in Table 7). These tests resulted in corrosion rates for " $A$ " nickel in $\mathrm{Cl}_{2}-15$ vol \% $\mathrm{CCl}_{4}$ about threefold higher ( 3 to $4 \mathrm{mils} /$ month) than in $\mathrm{N}_{2}-15$ vol $\% \mathrm{CCl}_{4}$ (Fig. 1I). This was the only case in which the corrosion rates in $\mathrm{Cl}_{2}-$ $\mathrm{CCl}_{4}$ differed significantly from the rates in $\mathrm{N}_{2}-\mathrm{CCl}_{4}$. The "A" nickel specimens fortunately were protected from chlorinating reagents by the oxide coat that they picked up during the oxygen portion of the cycle, and the overall corrosion rate was less than $1 \mathrm{mil} / \mathrm{month}$. Haynes 25 did not behave this way, and the overall cycle corrosion rate of 3 to 5 mils/ month was nearly as high as the 5 to $6 \mathrm{mils} / \mathrm{month}$ corrosion rate observed in $\mathrm{Cl}_{2}-\mathrm{CCl}_{4}$ (Fig. 11).

Corrosion rates during Darex ${ }^{26}$ and Fluoride Volatility 9 operations have been reported in detall elsewhere. The Darex corrosion data also 


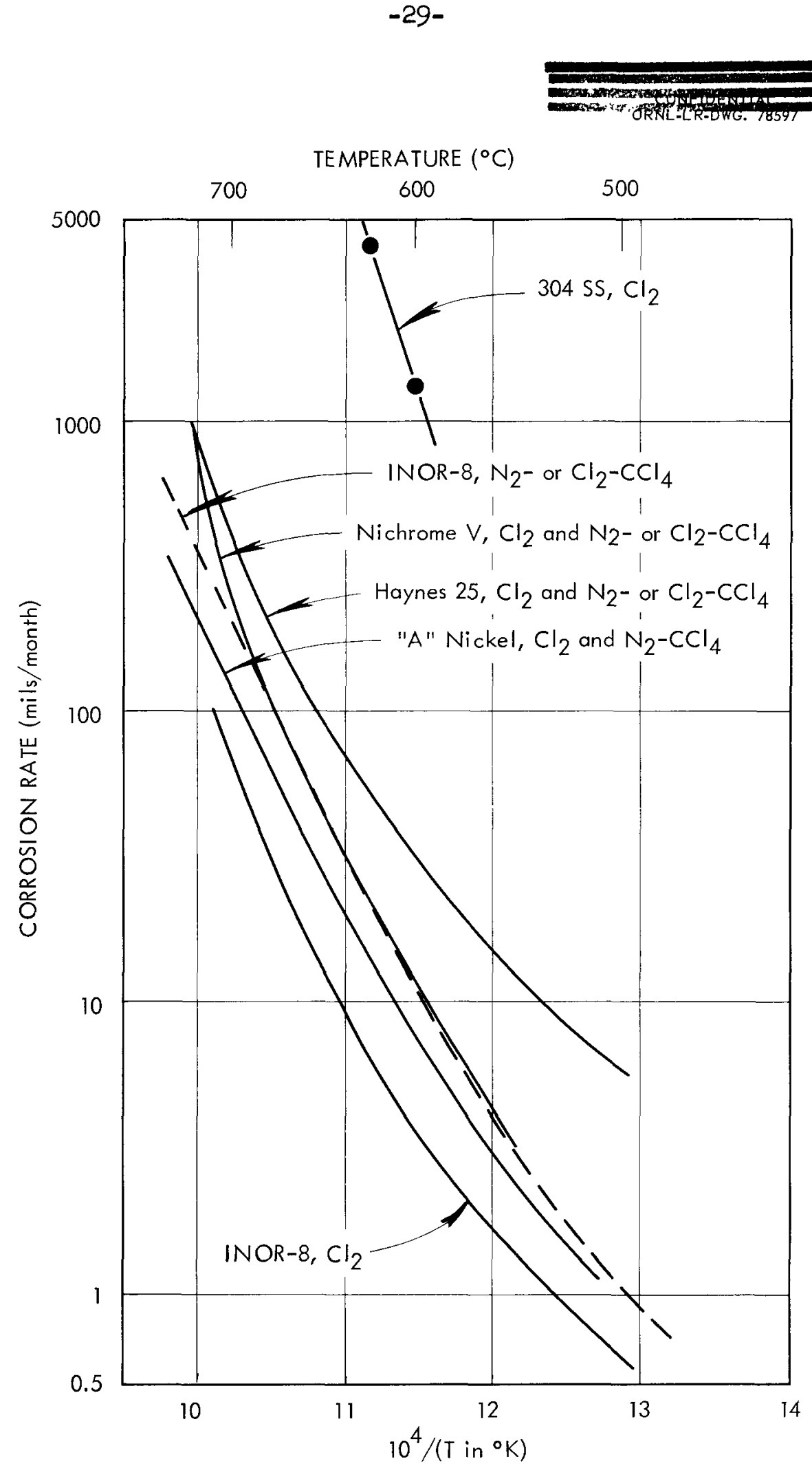

Fig. 11. Corrosion Rates of Metals in Chlorine and Carbon Tetrachloride Vapor as a Function of Temperature. (see ref 25). 
Table 7. Corrosion of Haynes 25 Alloy and "A" Nickel in 10-Hr Cyclic Testsa

(From ref 24)

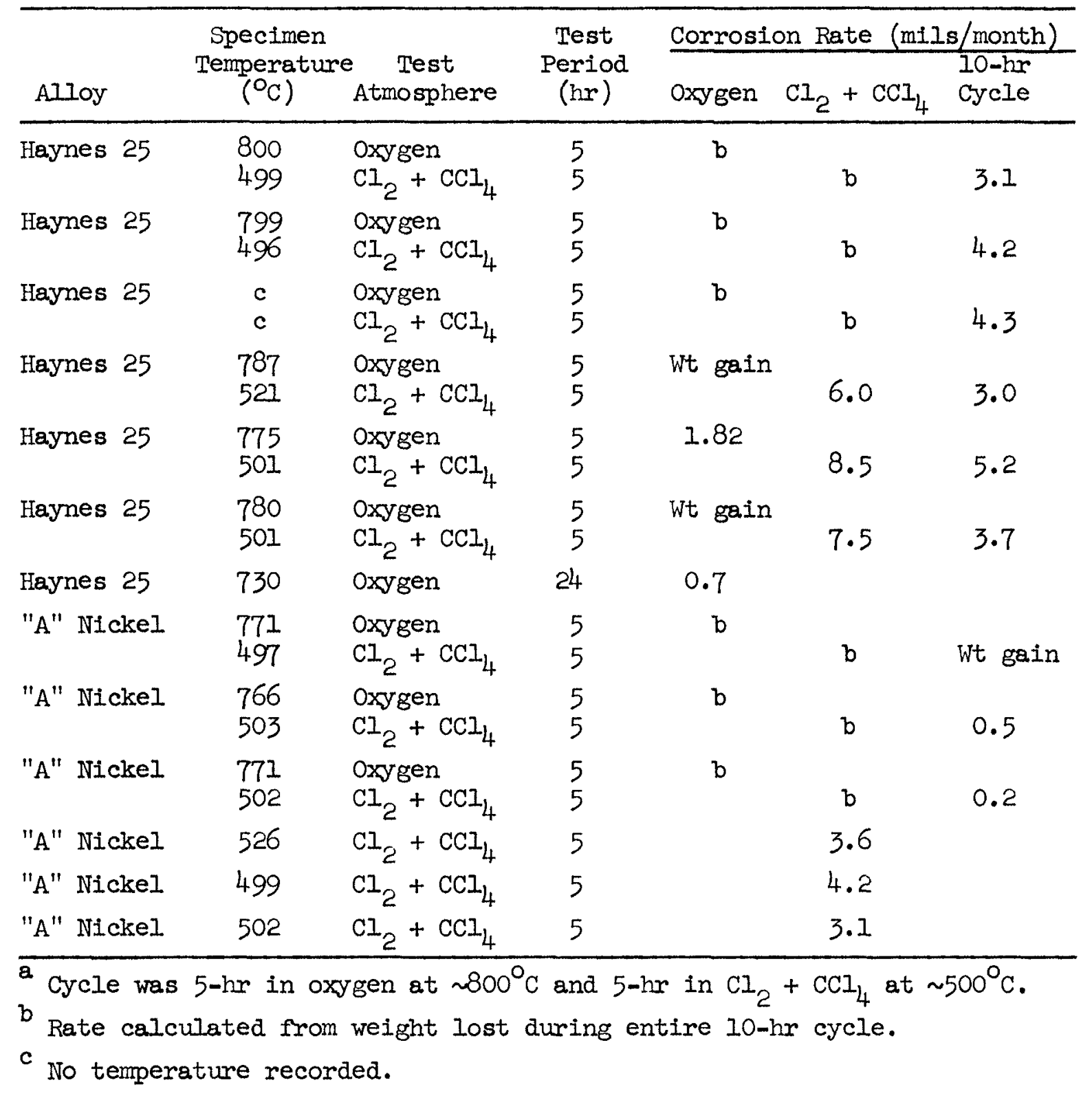

includes some high-temperature chlorination tests that indicate that Haynes 25 should serve well under the cycle shown in routes $b, c$, or $d$, shown in Fig. 1. 


\section{CONCLUSIONS AND RECOMMENDATIONS}

The combustion-chlorination process is more attractive than the other process, direct chlorination. The very favorable chemical kinetics and equilibria involved in the combustion-chlorination process, in the separation of uranium and niobium (and possibly fission products) by volatilization of niobium chloride (or perhaps by use of a salt bed) and in the hightemperature chloride-removal steps show the practicality of the development of a uranium recovery process for Rover fuel under conditions such that nickel or high-nickel alloys are suitable construction materials.

Chlorination processes, such as the combustion-chlorination process, are versatile. For example, the combustion-chlorination process described here is probably compatible with other high-temperature gas-solid chlorinations, especially the chlorination or hydrochlorination of zirconium alloy fuels. It may even be possible to conduct both of these processes in the same reactor.

Selection of the best of the several alternative processing routes discussed will depend mostly on engineering considerations, none of which has been given more than cursory attention as yet, as well as the particular circumstances influencing the processer. For example, the high-temperature chloride-removal operation might appeal to a processer who already has a TBP--nitric acid solvent extraction plant.

Early evaluation of one important engineering problem would be helpful in establishing the value of the combustion-chlorination process. On the basis of laboratory observations, the most difficult operation to engineer (with the exception of burning, which is receiving an independent study) ${ }^{6}$ will be the collection of volatilized chlorides, particularly niobium chloride. The sublimed niobium chloride is, under most circumstances, a low-density crystalline material which collects as masses of fluffy needles. This fluffy product may cause entrainment problems and make it necessary to use large collection vessels. On the other hand, entrained niobium chloride should be easily captured by simple, coarse filters because of its tendency to crystallize in long needles. In contrast to zirconium chloride for example, it might be possible to collect niobium chloride as a liquid. 


\section{REFERENCES}

1. Rover Report for June 1962, ORNL-TM-298 (July 1962) (Confidential).

2. J. C. Bresee, Review of Rover Fuel Processing Program of Chemical Technology Division, ORNL-CF-6I-II-5I (November 196I) (Secret).

3. L. M. Ferris, A. H. Kibbey, and M. J. Bradley, Processes for Recovery of Uranium and Thoriun from Graphite-Base Fuel Elements. Part II, ORNL3186 (November 1961).

4. L. M. Ferris, A. H. Kibbey, and K. S. Warren, Uranium Recovery from KIWI Fuel Elements: Laboratory Development. Part II, ORNL-3283 (In press).

5. T. A. Gens, Chloride Volatility Processing of Nuclear Fuels, ORNL-CF61-3-43, Accepted for publication in the Am. Inst. of Ch. Eng. Vol of Nuclear Engineering to be published in the fall of 1962.

6. C. D. Scott, Feasibility of the Oxidation of Graphite-Uranium Fuels with Oxygen. Preliminary Results, ORNL-CF-62-2-35 (April 1962) (Confidential).

7. "Columbium/Tantalum Special Report," Chemical Week, May 6, 1961.

8. J. W. Prados, Estimation of Reaction and Heat Release Rates for Graphite Oxidation, ORNL-CF-60-10-131 (October 1960).

9. G. I. Cathers, W. H. Carr, R. B. Iindauer, R. P. Milford, and M. E. Whatley, "Recovery of Uranium from Highly Irradiated Reactor Fuel by a Fused Salt-Fluoride Volatility Process," Progress in Nuclear Engineering, Series III, Vol. 3, Process Chemistry, Pergamon Press, New York 1961, p. 307.

10. F. G. Kitts and W. E. Clark, Darex Process: Processing of Stainless Steel-Containing Reactor Fuels with Dilute Aqua Regia, ORNL-2712 (May 1962).

11. J. J. Katz and E. Rabinowitch, The Chemistry of Uranium, NNES-VIII-5, McGraw-Hil1, New York, 1951, pp 464-467.

12. R. K. Steunenberg and R. C. Vogel, "Fluoride and Other Halide Volatility Processes," from Reactor Handbook, Vol II, "Fuel Reprocessing, " ed. by S. M. Stolier and R. B. Richards, Interscience Publishing Co., New York, 1961, p. 267.

13. J. J. Katz, 10c. cit., p. 501.

14. I. S. Morozov, "Chlorination in the Metallurgy of Rare and Nonferrous Metals," Journal of Applied Chem., USSR: 33, 1669 (1960).

15. T. A. Gens, The Chemistry of Niobium in Processing of Nuclear Fuels, ORNL-3241 (January 1962).

16. I. S. Morozov and B. G. Korshunov, "Investigation of the ChIorination of Niobium Pentoxide and Zirconium Dioxide," Chemistry of the Rare Elements: 2, -102-114 (1955) (In Russian).

17. Max Gloor, "Dampfdruck and Thermische Dissoziation von NioboxychIorid" (Thesis), Nuclear Sci. Abst. 16: 16398 (1962). 


\section{$-33-$}

18. I. V. Budayev and A. N. Volsky, "The Chlorination of Uranium Dioxide and Plutonium Dioxide by Carbon Tetrachloride," P/2195, Proc. and Internat'1 Conf. on Peaceful Uses of Atomic Energy, Geneva, 1958, Vol. 28, p. 316, UN, New York.

19. T. A. Gens and R. L. Jolley, New Laboratory Developments in the Zircex Process, ORNL-2992 (April 1961).

20. E. M. Levin and H. F. McMurdie, Phase Diagrams for Ceramists, Part II, The American Ceramic Society, Inc., Columbus, Ohio (1959), p. 83.

21. E. M. Levin, Ioc. cit., p. 89.

22. B. G. Korshunov and V. V. Safonov, "Reaction of Niobium Tetrachloride with Sodium and Potassium Chlorides," Russian Journal of Inorganic Chemistry: 6, 385 (1961).

23. Chemical Technology Division Monthly Progress Report for December 1957, ORNL-2468, pp. 11-12.

24. J. Van Wazer and G. John, "A Kinetic Study of the Oxidation of Uranium Tetrachloride," J. Am. Chem. Soc., 70, 1209 (1948).

25. L. Rice, Oak Ridge National Laboratory, Oak Ridge, Tennessee, private comunication to W. E. Clark (August 1, 1962).

26. C. I. Peterson, Construction Materials for Various Head-End Processes for the Aqueous Reprocessing of Spent Fuel Elements, BMI-1375 (August 195 
Blank Page 
$-35-$

\author{
ORNL-3376 \\ C-44b - Nuclear Technology-Chemistry \\ and Chemical Engineering \\ M-3679 (28th ed.)
}

INTERNAL DISTRIBUTION

1. Biology Library

2-3. Central Research Library

4. Reactor Division Library

5-6. ORNL - Y-12 Technical Library Document Reference Section

7-13. Laboratory Records Department

14. Laboratory Records, ORNL R.C.

15. R. E. Blanco

16. J. C. Bresee

17. K. B. Brown

18. Lloyd Carter ( $\mathrm{Y}-12)$

19. G. I. Cathers

20. F. L. Culler

21. D. E. Ferguson

22. L. M. Ferris

23. B. C. Finney

24. T. A. Gens

25. H. E. Goeller

26. B. A. Hannaford

27. R. W. Horton
28. F. G. Kitts

29. G. B. Marrow $(Y-12)$

30. L. E. McNeese

31. E. L. Nicholson

32. A. D. Ryon

33. W. F. Schaffer

34. C. D. Scott

35. M. J. Skinner

36. S. H. Smiley, ORGDP

37. J. A. Swartout

38. J. W. Ullmann

39. C. D. Watson

40. A. M. Weinberg

4I. M. E. Whatley

42. H. B. Whetsel

43. J. J. Katz (consultant)

44. T. H. Pigford (consultant)

45. C. E. Winters (consultant)

46. H. Worthington (consultant)

\title{
EXTERNAE DISTRIBUTION
}

47. E. I. Anderson, Jr., AEC, Washington

48. R. D. Baker, ILASL

49. D. C. Davis, ORO

50. L. P. Hatch, BNL

51. J. A. McBride, ICPP

52. W. S. Scheib, AEC, Washington

53. J. I. Schwennesen, AEC, Washington

54. G. Strickland, BNL

55. L. C. Corrington, SNOP, Cleveland

56. Research and Development Division, $A E C, O R O$

57-245. Given distribution as shown in M-3679 (28th ed.) under Nuclear Technology-Chemistry and Chemical Engineering category 